\title{
The Knight and the King
}

There are two themes that seem to be present in literatures all over the world: love and war. These themes are not only found in all literatures; they are also persistent in literature in all times, as if they represent the basic material of which literature is made or, more fundamentally, the basic human experience that necessitates the phenomenon of storytelling. Whatever may be the case, since, as we have seen, kingship is a basic theme, too, it seems fruitful to link the literary representations of love and war to notions of kingship and its place in the social and cultural imagination. In Chapter Five we will discuss some significant love romances; in this chapter we will turn our attention to six examples of chivalric romances that occupy a crucial position in the literary traditions in which they emerged and which seem eminently suitable for the purposes of this essay. As we will see, the texts not only fulfil the criteria of our selection of material; they also provide sufficient food for thought and speculation.

In order to introduce the romance of chivalry as a generic type and illuminate its relationship with our topic, we will first briefly discuss a specific narrative that appeared in the later versions of the Thousand and one nights: the story of 'Ajib and Gharib'. This story is one of the two chivalric romances in the Nights (the other is 'Umar al-Nu'man and his sons') and is rather austere as a narrative, interesting more for its structure - and perhaps for its historical references - than for its imaginative details. It is considered by some to be a derivative from the much longer and more elaborated romance Hamzanama, which will be discussed below. The story of 'Ajib and Gharib' will allow us to determine the basic ingredients and strategies involved in this type of text. It should be noted here, that in all the literary traditions involved, the genre of the chivalric romance in the period under study is tightly linked to an earlier substratum of romances, from which it evolved and, of course, deviated.

The story of 'Ajib and Gharib' can be summarized as follows: King Kundamir of Kufa (Iraq) begets a son at an advanced age. The child, called Ajib, is entrusted to a priest, but he turns out to be recalcitrant and disobedient. When he grows up, he murders his father and usurps the throne. In a dream he sees a bee coming from his father's penis, which morphs into a lion attacking him. The explanation of the dream by the soothsayers is that the king will have a half-brother who has to be killed because he will be a threat to his rule. It turns out that there is a pregnant slave-girl in the harem, who is now taken away to be 
executed. The slave-girl survives, however, and bears a son named Gharib. She is taken as a wife by a tribal chief and has another son by him, named Sahim alLayl. Gharib grows up to become a fierce hero, and when one day the camp of the tribe is attacked, he rescues Mahdiyya, the daughter of the chief. He falls in love with her, but the chief is reluctant to give her in marriage to him, because she was promised to someone else. He sends Gharib away on an impossible mission: He should defeat the giant who lives in the palace of the legendary Arabian king Ham ibn Shayth ibn Shaddad ibn Khald.

On the way to fulfil his mission, Gharib encounters an old sheykh in a cave, who is 340 years old and was a member of the tribe of Ad, the legendary Arabian hero. Ad's tribe was summoned to convert to the true faith of Ibrahim by the Prophet Hud, who was, however, despised. The whole tribe was exterminated except this sheykh, who accepted conversion. Gharib, convinced of the veracity of the faith, pronounces the shahada in the God of Ibrahim and his troops follow his example. The sheykh tells him that the giant whom Gharib has to kill is a fearsome man-eating ghul, who descended from the tribe of Ham and Hind, the ancestor of the Indians. He was sent away because of his anthropophagy. The sheykh gives Gharib an iron rod with ten rings of a hundred pounds each, a sword of three yards length, forged with lightning, a shield, a coat of mail, and a Qur'an. Thus armed, Gharib, still a beardless boy of three feet high, defeats the ghul, who converts to the true faith. Gharib ascends the throne, which once belonged to Sasa ibn Shayth ibn Shaddad ibn Ad, and has Sahim seated at his right hand. He releases the prisoners held by the ghul, among whom is Fakhrtaj, the daughter of the king of the Persians, Daylamites, Turks, and Fire-worshippers. Her father, coming to her rescue, confronts him, but he defeats the Persian. Fakhrtaj wants to marry him and her father now agrees, but he demands that he first kill the rival king al-Jamrakan. Gharib takes part in a tournament with a lance to which a piece of saffron cloth is attached. Afterwards, he loses his way in the royal palace, ends up in Fakhrtaj's bedroom, and makes love to her.

The following parts of the story relate how Gharib takes revenge on the villains who tormented him, his mother, and his father in the past. He is at the summit of his power, and Sahim calls him king of the Persians and the Arabs, son-in-law of Khosrau, the King of the World. During his campaigns he succeeds in converting many tribes, and at some point he sends a letter to Ajib, summoning him to convert. Ajib flees, however, and Gharib occupies the throne of Kufa. When one day he falls asleep in a meadow, he is abducted by jinns, who take him to King Mar'ash, a fire-worshipping jinn, who venerates an oven with coloured flames. Just before Gharib is thrown into the fire, the oven is destroyed by a falling merlon. When Gharib is placed on an auto-da- 
fe and God sends rain to extinguish the flames, Mar'ash converts to the faith. Gharib now helps him in his struggle against his jinn rivals and is presented with al-Mahik, the sword that once belonged to Jafith ibn Nuh (Jafeth the son of Noah), and a winged horse. Moreover, Gharib meets the lovely Kawkab alSabah, the daughter of the Blue King and a Chinese mother, and falls in love with her. After Gharib is shown the jinn realm of Mount Qaf, he returns to the human world. He sleeps with Fakhrtaj and is officially married to Mahdiyya. In a final episode Gharib miraculously travels to India, unmasks an idol in which a jinn is hidden, and kills a sorceress who wants to possess him. The story ends with the meeting with his—fully grown—son Muradshah.

This brief summary serves not as a starting point for a discussion of the story itself, but rather as a model of the basic characteristics of the genre. Of course, not all narratives discussed below comply with the model and all its characteristics, but these are possibly interesting divergences from the generic type. Some of the basic characteristics are the following:

[1] The stories are usually constructed according to the so-called 'adventure trope', that is, they follow the hero during his peregrinations from his birth or youth until his manhood, describing the obstacles on the way to the fulfilment of his mission, which is, on the one hand, adulthood and personal accomplishment and, on the other hand, the attainment of his position within the society in which he is destined to assume his task as a ruler. Often this trajectory is divided into phases marking a process of transition and concluded with legal matrimony to his beloved and, for instance, with his succession to the throne. It should be noted that in the stories discussed below the love component is usually subordinated to the martial role of the hero, and the ideal composition of the romance is sometimes affected by the historical framework in which the story is set. In some cases the story does not end with the hero's apotheosis, but with his death. An example of this kind of story has been analysed in the previous chapter: the framing story of Manuscrit trouvé à Saragosse is reminiscent of the medieval trope of the knight/prince on his way to adulthood.

[2] The generic conventions stipulate that the characters of the story, including the hero, are rather flat and emblematic. The hero does not complete a trajectory of psychological growth, but is from the beginning hewn from one piece, so to speak. Gharib is already strong at an early age, and his only development is his conversion to the true faith. He takes few decisions on his own initiative, but rather responds to events and encounters that impose themselves upon him and spur him on to fulfil his destiny, 
without much contemplation or psychological depth. Like the other characters, the hero acts out a stereotypical role that stands for a certain moral type. The hero, of course, represents strength, uprightness, intelligence, courage, inventiveness, and other virtues (though not chastity).

[3] In his emblematic, stereotypical, role the hero instils not only certain values in the story, but also the element of chosenness. He is chosen as a kind of saviour to establish a certain order, which is usually related to religion. His eminence is foretold by the stars, or in a dream, or by some auspicious omen. He is from his early youth recognized as a hero, because he already embodies the virtues with which he is destined to impregnate society. He is the personification of a just cause, which will usually bring salvation to the community by slaying its enemies and the forces of evil. This restoration of order and the charisma which it requires are connected with 'eternal' values, especially religion, and are symbolized by forms of conversion, the conjuring of sorcerers and demons, and the expulsion of evil. To stress this historical role, the hero is usually endowed with objects that indicate his chosenness, such as magical weapons or horses that once belonged to legendary predecessors. Sometimes they receive titles that link them to a glorious past or to legendary heroes. This enhances their legitimacy by linking them to history, tradition, and legend, and the collective memory of the community. They are not only invincible; they are rightly so, because they represent the combination of virtue and strength as it has been sanctified by history.

[4] The story line of the narrative is usually set in motion by a disruption, such as the death of a king/father, or the looming fall of the dynasty, or something of the kind. The hero represents the force of continuity and reconstruction, of the revitalization of ancient values that are the foundations of the community. In some cases he is at the beginning of this history, as the co-founder of a nation.

[5] The hero is in some way solitary in his supreme prowess, but he is always surrounded by loyal comrades, helpers, and adjutants. Some of these have stereotypical roles, such as the loyal friend, the trickster, the gluttonous bully, etc. The hero thus forms a kind of band based on sworn loyalty and a division of tasks, which, of course, are helpful in the design of the plots, the breaking of stalemates, and the resolution of intricate situations. A special role is usually reserved to women, either as helpers or as beloveds, or both. Women, too, of course, represent forms of legitimacy and continuity, through their position, descent, and offspring.

[6] A crucial element in the stories is the enemy personified by a foreign king, a wicked vizier, or a rebellious governor. In several cases the hero is him- 
self not the ruler. This produces a complex set of relationships between the various components of the power structure, each representing a specific form of power. As we will see, it is within this complexity that notions of power and authority are defined, precisely because of the differentiation it implies. Needless to say, the villains are stereotypes, too, personifying the very essence of evil.

[7] Finally, the story usually unfolds within certain demarcations indicated by cultural or geographical boundaries. These boundaries can be used merely as a device to construct the story, creating differences, oppositions, (im)possibilities, obstacles, etc., but they can also be used as a means to indicate adherence to specific communities, thus embedding the struggles and the structures of power and authority within a specific milieu. This milieu may be linked to all kinds of communal identifications: political, cultural, religious, or historical. It is here, together with other historical references, that a certain legitimation is sought and the ideological significance of the narrative is articulated.

In the following sections these basic elements of the chivalric romance will be regularly referred to, although, as remarked above, they are not equally relevant for all cases. Still, in the conclusion at the end of our analysis we will be able to point to some remarkable similarities. For our discussion we have selected six romances, from the European, Persian/Urdu, Chinese, Arabic, Malay, and Turkish traditions. All of the texts have ancient roots in previous literary works or trends, but have also survived at least until the rise of early modernity, proving their resilience to innovative trends or their ability to assimilate new elements and tastes. They all hover in the diffuse area between official and popular discourses in the various aspects determined in the introduction.

\section{Tirant lo Blanc: The Ideal Knight}

One of the landmarks in the history of European literature, and probably in world literature as a whole, was the appearance of Cervantes's masterpiece Don Quijote de la Mancha in 1605/15. The work is not only immensely fascinating in itself, but also marks the transition from medieval literature-especially romances of chivalry - to (pre)modern literature, which came to be dominated, over the course of time, by various forms of the novel. It closes the period of the great romances, which thrived in medieval Europe, and opens up new vistas of literary art based on a new perception of literature. One of the interesting aspects of Don Quijote is that it is apparently itself conscious of 


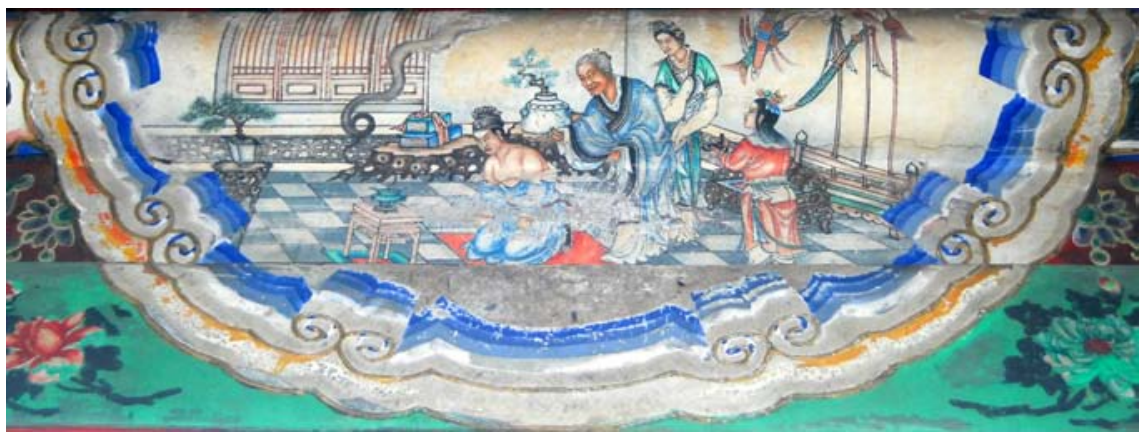

FIG U 5 Yue Fei's mother tattooing Yue Fei, Beijing Summer Palace, 18th century.

its innovative role. It not only presents a parody of the literary genre it aims to replace, the author also comments on the literature of his time and suggests a literary background that is both culturally and narratively complex. Whatever may have happened afterwards, Don Quijote, as a work of literature, is a monument indicating and representing new outlooks on life and history.

One of the literary works discussed and praised by Cervantes is the Catalan romance Tirant lo Blanc, which was initially written by Juanot Martorell and completed by Marti Joan de Galba, and which appeared in print in 1490. It was translated into Castillian in 1511 and into Italian in 1538,1566 , and 1611. It subsequently became known throughout Europe. The work was written in a period when Catalan culture and literature witnessed a remarkable upsurge in the work of Ramon Llull (1233?-1316?) and Ramon Muntaner (1265-1336), and the romance Curial e Güelfa (app. 146o). This new cultural effervescence was, of course, related to the prominent role of Catalan towns in the Mediterranean trade networks of that time. It is partly inspired by the adventures of Roger de Flor, who, with a following of Catalans, undertook an expedition to the Levant and for several years settled in Macedonia, entangled in the many intrigues surrounding the Byzantine emperor and his struggle against the Muslims. He wrote an account of this expedition, which in outline resembles the martial exploits of Tirant. Another source was Ramon Llull's Llibre de l'Orde de Cavalleria (Book of the order of chivalry, 1274-1276) which is an elaborate compendium for the order of knights in Europe.

These references indicate that the narrative of Tirant has clear roots in its historical context. It refers to historical figures, albeit fictionalized, and clearly reflects a historical situation, both the state of the chivalric 'class' in the late Middle Ages and the political and military challenges relating to Constantinople, which was conquered by the Ottomans in 1453. The loss of Constantinople was, of course, a major setback for the European/Christian kings and was 
everywhere interpreted as an event of almost apocalyptic proportions. The many epic stories that emerged in Europe in the fifteenth and sixteenth centuries, which often involved expeditions to Constantinople, can be seen as an effort to reconquer the city within the literary imagination, or at least to assert some rights to the area from a Christian perspective. The Grand Turk replaced the Saracens as the great Muslim threat to Christianity after the last bulwark against Islam had fallen.

The historical framework of the romance has a bearing on its narrative concept. The story is different from the medieval romances in the sense that it is less abstract and romanticized and the characters are (relatively) less emblematic, a realism praised by Cervantes. The book is an inventory of the ideals of knighthood, which have developed into its ultimate sophistication, while becoming increasingly outdated at the same time. The virtues of the knights are celebrated, but the reader knows that the era of the valiant warrior is past and has been overtaken by history. The values expressed in the work have developed more in the direction of a pristine humanism, with a sense of realism, a concern for details of personalities, and a tendency to see characters not merely as passive vehicles for the story. Descriptions of scenes and persons can be remarkably detailed; emotions and contemplations are elaborated upon; and supernatural phenomena are almost completely absent. The novel thus finds itself, like Don Quijote, on the boundary between the medieval romance and the (pre)modern novel.

Still, in spite of these 'modern' features, the writer links the story quite explicitly to the European chivalric tradition. The story opens with an episode relating the adventures of the English knight William of Warwick, the 'father of knighthood, who explains to the reader the origin, vocation, tests, weapons, and customs of the phenomenon of knighthood. We learn that William went on pilgrimage to the Holy Sepulchre in Jerusalem and subsequently disappeared, giving rise to the rumour of his death. He has retired to an isolated cabin in England to atone for his sins. However, when the English king is defeated by an invading band of Moors, he (the king) sees a bearded man in a frock taking charge of the army. When he meets William - whom he does not recognizehe asks him to lead his army. He even descends from the throne to allow William to assume the corresponding dignity. William consents and a document is drawn as proof of the transaction. Because he knows Arabic and has learned how to use explosives, William succeeds in expelling the Moors, and after his victory the king is restored to the throne.

Next, we are told how a lonely traveller falls asleep while riding his horse and is taken to a hermit-William-who is reading the Tree of the martial arts. This is Tirant lo Blanc, a Breton nobleman, on his way to the English court to 
take part in a tournament. William reads passages from the book to Tirant, explaining to him the basic rules of knighthood, the symbolism of weapons, and the traditions of warriors from the Bible, Antiquity, and the Middle Ages. Armed with this knowledge, Tirant continues his journey to the court of the English king, where knights from all over Europe gather to prove their prowess. They have to swear an oath:

Oh gentleman received into the knightly order, do you swear before God and on the four Gospels never to contravene the most lofty and excellent King of England except in the service of your natural lord, and then only after returning the chain with his arms that he now places upon your neck? Only thus may you oppose him without incurring worthy knights' reproaches, for otherwise you will commit treason and deserve ill repute, and should you be taken prisoner, you will risk death at his hands. Therefore, do you now swear to champion ladies, widows, orphans, damsels in distress, and also married ones, should they request your aid, cheerfully braving death if one or more of these should call upon you? ${ }^{1}$

Of course, Tirant beats all his rivals and is formally incorporated into the knightly Order of the Garter, newly founded by the king. The young knight sets out to discover the world, and after some adventures around the island of Rhodes and a pilgrimage to Jerusalem and Alexandria, Tirant is asked by the emperor of Constantinople to help him in his struggle against the Turks. Tirant makes his preparations, equips a ship, and sets sail to the east. His real adventures start here.

The remainder of the narrative can be divided into two parts: first, Tirant's adventures as a general of the Byzantine army, his struggle against the Turks, the intrigues with the Greek noblemen, and his love for princess Carmesina; and, second, his adventures in North Africa, after his ship is blown off course to the African coast by a sudden storm. Here he becomes involved in wars between the regional kings, whom he finally converts to Christianity. The African episode, like Gharib's excursion to the realm of the jinns, is interesting in itself, but it is mainly an intermezzo inserted into the main story, which takes place in and around Constantinople. Tirant succeeds in repelling the Turkish troops from Byzantine territory and concluding an advantageous peace treaty. He also succeeds in conquering the heart of princess Carmesina, the daughter

1 Joanot Martorell and Martí Joan de Galba, Tirant lo Blanc, trans. David H. Rosenthal (London, 1984) 74 . 
of the Byzantine emperor, who is actually the main protagonist after Tirant. Just after Carmesina has become his bride, however, Tirant falls ill and dies. The princess and the emperor also die, of grief.

Although, as said above, Tirant lo Blanc is in several respects more complex than the average romance of chivalry, it exhibits some of its basic narrative structures. The story begins with a transition, in which the young hero Tirant, apparently guided by fate, meets the old warrior William of Warwick, who instructs him on the principles of knighthood, based on his own experiences as a knight and on the established rules and conventions laid down in books and history. Thus, the interruption of a tradition is prevented, and Tirant is provided with the knowledge required for his role, just as a young prince may receive instruction before he succeeds his father. Like many motifs of this kind, the knowledge is conveyed through dialogue, making use of references to texts of a specific kind. After this introduction the story is constructed basically as the conventional adventure trope in which the intrepid hero is catapulted towards the scenes of his destiny by his unbounded ambition, conquering obstructions on the way and unfailingly realizing all his projected aims, being rewarded in the end with the legal possession of his beloved. His being blown off course and away from the main story is a typical device of the contingency of the adventure trope. Still, this skeleton of the story is fleshed out to such an extent that the mechanical dynamics of the story and the emblematic nature of Tirant as a narrative character are enriched not only with elaborate and detailed descriptions, but also by the efforts to mould Tirant into a more or less realistic hero, who has his feelings and doubts, his weak spots and his adversities. He is the paragon of virtue and righteousness, but he is also a man trying persistently to still his desire for Carmesina, even breaking a leg in an attempt to steal into her bedroom.

A significant element enhancing the realistic impression of the story is the framing of events within formal transactions and documents. This starts immediately at the beginning, when William of Warwick uses the chivalric handbooks as an authoritative source. During the tournament at the English court not only is an oath taken by the participants; the whole struggle is regulated by formalities and functionaries, such as 'weapon kings', judges, and notaries. Some of the participants have a special official certificate issued in Rome by cardinals and clerics, proving that they are genuine knights 'of four quarters' (father, mother, grandfather, grandmother). The foundation of the Order of the Garter is also recorded in documents, including the oath, the proscriptions, the grants, the pledge of faith, the protection of the Holy Land and of women, and the membership of a number of ladies. This inclination towards formalities was apparently a new phenomenon, which was not wel- 
comed by the author, since he has the English king kill all the jurists because their only aim is to enrich themselves. The advice is 'to allow only two jurists in the whole country, who in all cases have to conclude with a sufficient verdict within fourteen days.' ${ }^{2}$ They should receive a salary so that they will not take bribes.

In spite of all the efforts to imbue the story with a sense of realism, Tirant is still sufficiently 'super-human' to fulfil his role in the story. He is not only privileged as a chosen knight through his initiation by William, the quintessential knight; he is also strong, courageous, and intelligent, full of self-confidencewhich melts away only in the face of love-and with an unflagging sense of purpose. He is righteous and charismatic, conscientious and just, and caring for the common people. He is not interested in earthly possessions or status, but only in his prestige as a knight: His only possessions are honour, weapons, and a horse. His task is to obey and to assist: to obey his king and the Holy Church and to protect their interests wherever he can, remaining faithful to his oath. Honour is self-evidently related to religion: every action and transaction is accompanied by Holy Masses and other ritual celebrations, and Tirant's mission is triggered by his hearing a messenger who reports that the Turks have invaded Constantinople and are refurbishing the cathedral as a stable for horses. Although the emperor seems to acquiesce in his misfortune, a knight should jump up and defend the Church and the people of God. Other religious motifs are Tirant's pilgrimage, the thorn of Jesus's crown preserved in the castle of Rhodes, and many conversions.

Religion is not only at the heart of Tirant's mission in life; it is also what distinguishes good from evil, the just cause from its enemies, God's community from its attackers. The personification of evil is, of course, the Ottoman sultan and his army commander called the 'Grand Turk'. The Turks are not only accused of violating Byzantine territory, abducting Christian children, and threatening to convert churches into stables; they are also the archenemy of the faith, the adherents to a false belief. The sultan is in league with the kings of Asia, Africa, Cappadocia, Armenia, India, and Egypt, as the head of a political coalition, and therefore is the embodiment of the false and objectionable faith of Muhammad. During his struggle in Africa, fighting the combined forces of the kings of Bejaïa, Fez, Persia, Tana, Nether-India, Damascus, Granada, and Tunis, Tirant delivers a passionate tirade against the Muslims, who seek their happiness in gluttony and adultery, as exemplified by the dissolute 'swine' and deceiver Muhammad. It is a faith in contradiction to reason, meant for

2 Ibid., 57. 
irrational animals. Tirant refers to Aristotle, Preacher 23, John 12, Paul's first letter to the Corinthians, and Proverbs 6. When he has finished, 340,ooo Moors are willing to convert.

The enemy is defined not only as a religious community, but also geographically, although the demarcations are a strange mixture of vague and imprecise indications. Opposite the Asian/African realm of the 'heathens' stands a mosaic of European kingdoms. At the joust in England knights participate from France, Poland, Bavaria, Burgundy, Austria, Aragon, Castile, Portugal, Navarra, Exeter, Wales, Bedford, and Friesland. Although the name Europe is not mentioned, it is clear that the tradition of knighthood and, perhaps more importantly, the networks of knights and knightly courts were seen as a common European phenomenon. But since it was ideologically unified by the common faith, it was the head of Christendom, the Emperor of Constantinople, who represented the paramount position and the symbolic authority within this common tradition. This is partly due, of course, to the heritage of the Middle Ages and the tradition of the Crusades. In Tirant, too, the oath to fight for the Holy Land was a crucial part of the chivalric code.

The realm of the Christians is therefore imagined in a rather ambivalent way, combining symbolic, religious, geographic, and political elements. There is no strict unity. Tirant scolds the perfidious Genuese, Lombards, and Italians, who conspire with the Turks. Conversely, some Turks are depicted as civilized, trustworthy men, eloquent, brave, wise, and decent. Politically, the rather inchoate mixture of Byzantine nobles and the auxiliary troops from the European kingdoms, led by their various commanders, is regulated through functions and ranks, integrating, to some extent, the different hierarchies involved. This is symbolized, too, by ceremonies and paraphernalia, such as the various crowns: the duke wears a silver crown; the count a leather crown; the marquis a steel crown; the king a golden crown; and the emperor has seven golden crowns. This hierarchic division of external marks reveals a differentiation within a single system unifying the empire with the European kingdoms based on the common codes of knighthood.

A curious episode occurs when a court meeting in Constantinople is surprised by a visit from Morgana, the sister of King Arthur, who is desperately searching for her brother. The emperor leads her to a dungeon where a knight with the sword Excalibur resides. The knight, who is King Arthur, speaks about the condition of royal dignity, the properties of ladies, the eight 'natural gifts', the oath of enthronement, the origin of honour, and the duties of warriors, the prince, and the vassals. After his lecture Morgana leaves Constantinople and Arthur is not mentioned again. It is not explicated what this passage is meant to add, but it seems to have been inserted to emphasize the link between 
the Byzantine Emperor and the heritage of the great, quintessential king of the Christian realm, and, additionally, of the European literary tradition. If the codes of chivalry are evoked recurrently throughout the book, suggesting that it is the tradition of knighthood that is reiterated, celebrated, and preserved within the narrative, it is this staging of the legendary king that reveals various manifestations of the tradition. There is a line connecting King Arthur with the Byzantine Emperor, and it is upheld by the tradition of chivalry. It is here that the various strands within the discourse of kingship in Tirant converge: the tradition of knighthood, the great European kings, and the symbolic authority of the Byzantine Emperor. Tirant personifies the values inherent in this system and also serves as a medium connecting and conveying them, as an indispensable support for the system and its main symbol, the Byzantine Emperor.

Before we proceed with our discussion of other romances, a final note should be added about the role of women in the story of Tirant. In contrast to most of the texts discussed above, in Tirant, as in other romances, the role of women is not essentially negative. From the beginning it is made clear that women have a specific position within the chivalric system, mainly as ladies to whom the knight dedicates his exploits, but also, within court circles, as the beloveds of the knights. The formation of love pairs is attributed to love and passion, but it is obviously governed by hierarchies, ranks, and conventions, and, to be sure, by narrative patterns that impose a certain balance between the characters. It is no coincidence, of course, that Tirant catches the highest prize, the gorgeous princess Carmesina. His courting of the princess occupies a substantial part of the narrative. For reasons of propriety, the relationship between the two lovers is hampered by conventions, delay, misunderstandings, and deliberations. Repeatedly debates are inserted about the condition of love and the nature of women, in which references to examples from Antiquity abound. The mighty warrior Tirant, who never recoils before any danger, is clearly dumbstruck by the force of his emotions and becomes like wax in the hands of his beloved. Carmesina, too, elaborately reflects on her desires, and the youthful vitality of the couple results in a number of erotic trysts, which are remarkably explicitly described. The erotic scenes are so vivid that one can see why the reading of romances of this kind was discouraged for young ladies and men.

In spite of Cervantes's scorn of the romance of chivalry, and Tirant's heralding of a new literary era, the genre experienced a revival in Europe in the sixteenth century. As we will see below, some story-cycles, such as the Amadis and Palmerin d'Oliva series, became enormously popular throughout Europe. Originating in the Iberian Peninsula, they were translated into several languages and were read primarily in court circles, but also by a wider audience. These 
novels, like Tirant, are situated mainly in the Mediterranean basin and are constructed around the confrontation with the Turks and the fall of Constantinople. Although the romance of chivalry died out after the sixteenth century, as we will see, the themes of the struggle against the rival faith and of the glory of knighthood remained popular in European literature throughout the seventeenth and eighteenth centuries and up to the novels of Walter Scott. The main focus of the works shifted, but the notion of warfare and adventure remained fascinating and relevant, and resulted in various forms of medievalism and orientalism.

\section{The Harbinger of the Faith: Amir Hamza}

In Muslim Asia, the genre of the heroic romance is dominated by two major clusters of texts: the Alexander romance, in its various appearances, and the Shahnama written by Firdawsi in the tenth century. These works were, so to speak, centres around which the material of narrative traditions coalesced to form nodal points and vehicles for transmission and presentation. They provided narrative models, characters, and intrigues, which could be endlessly elaborated upon or from which storytellers could freely derive their material to construct new narratives suitable for their times. Gradually a reservoir of material was formed that, because of the succeeding waves of linguistic and cultural amalgamation, fed into the chivalric traditions in Persian, Urdu, Turkish, and Arabic, and even Malay and Javanese. These traditions obviously evolved over the course of history; they cluster around historical figures and reveal the interactions between oral and written, and official and popular forms of literature.

One of the most well-known Asian romances is the Hamzanama, or the Book of Amir Hamza. The origins of this narrative are lost in the shades of history, but some scholars trace them back to the court of the Ghaznavid Sultan Mahmud (971-1030), who founded the first Muslim kingdom in Afghanistan. The work emerged in the full light of history during the reign of the Mughal Emperor Akbar (r. 1556-1605), who had an illustrated copy of a Persian text made, containing a great number of large, quite spectacular, miniatures. The book was subsequently stolen by the Persian Sultan Nadir Shah Afshar (1688-1747), the last Persian king to invade India. The romance remained popular among storytellers and poets in India, Afghanistan, and Persia during the seventeenth and eighteenth centuries, and its popularity has endured even until the present day. The text has been preserved in Persian and Urdu versions in manuscripts from the eighteenth century. These texts are roughly the same, but differ from 
the Arabic versions titled Qissa amir Hamza al-Bahlawan. In 1855 the Urdu text was edited by Ghalib Lakhnavi, and in 1871 this text was revised by Abdullah Bilgrami. It was translated into English in 2007 by Musharraf Ali Farooqi. The version that is extant is thus rather new, but as we will see, it has retained the traces of its long and rich history, combining ancient motifs with later additions and preserving not only a treasure of narrative material, but also the core plots and themes. Our discussion will be based on the English translation by Farooqi.

The main protagonist of the story is Hamza, the son of the paternal uncle of the Prophet Muhammad, Abd al-Muttalib. Hamza was thus a historical figure from the time of the prophet, who was killed in the battle of Uhud in 625 by a woman named Hind, in revenge for the death of her father. The other main character is the Sassanid Emperor Anusherwan I, the Just, who reigned between 531 and 579, that is, just before the birth of Muhammad. As in 'Ajib and Gharib', the narrative therefore predates the revelation of the Qur'an, although Hamza already prefigures the values and spirit of Islam and strives for the conversion of the Persian Fire-worshippers to the true faith. Like Gharib, he embodies God's plan and the course of history before the revelation, and the main theme of the story is the struggle between an old order, represented by the Sassanid Emperor, and the heralds of a new era. Unlike Gharib, but similar to Tirant, Hamza is not predestined to become the new king. He remains the loyal servant of the powers that be, revealing the inherent deficiencies of the old order and preparing the establishment of a new order without himself toppling the emperor or taking his place.

The story begins with an introductory episode in the reign of Anusherwan's father Qubad Kamran, Emperor of the Seven Concentric Circles (Climes) and of the world, who rules in Ctesiphon, its capital. It is a time of justice and prosperity; the king is even more courageous than the legendary hero Rustam, and his forty viziers are wise and well versed in physics, arithmetic, geomancy, divination, and astrology, outshining even Aristotle, Plato, Galen, Euclid, and Pythagoras. He has a sage, Bakht Jamal, who is a descendant of Danyal and who excels in the occult sciences. A prophecy reveals to Bakht Jamal that in the next forty days he should not leave his house, because misfortune looms. The sage stays at home for thirty-nine days, but on the fortieth day he goes out to visit his disciple Alqash. On the way he coincidentally finds a cellar with the seven treasures of the legendary Arabian King Shaddad. He reports his find to Alqash, who kills him, buys the property, and has a garden planted over the cellar. The wife of Bakht Jamal is pregnant and gives birth to a splendid child whom she calls Buzurjmehr. When he grows up she tells him: 'Son, your father left us nothing that I can spare to be sold for meat and drink. But on the 
shelf there lies an ancient book, belonging to my father, and written long ago. Many a time, when your father was in need of money, he resolved to sell it. But every time he reached for it, a black serpent would dart out hissing from the shelf.'3

The book of his grandfather is a magical text that shows Buzurjmehr the past and the future; he reads that his father was killed by Alqash, that he will revenge his death, and that he will become a vizier. Buzurjmehr becomes a pious and clairvoyant sage, the grandson of Hakim Jamasp, and Alqash intends to kill him. When the emperor has a dream, Buzurjmehr has the opportunity to show his skills. He explains the dream and exposes Alqash. He receives the vizier's robe and permission to be seated on the right side of the throne. According to the emperor, Buzurjmehr is versed in etymology, syntax, logic, ethics, mathematics, rhetoric, astronomy, geometry, letters, arithmetic, philosophy, geomancy, astrology, statecraft, economics, etiquette, and finances. The daughter of Alqash is married to a slave and the couple has a son. The emperor wants to have the child killed, but Buzurjmehr stops him and promises to educate the boy to become a vizier. His name is Bakhtak, and he will become the bitter adversary of Buzurjmehr, permanently conspiring against him to thwart his plans.

At the same time the emperor's spouse is pregnant. To ascertain the precise moment of birth, Buzurjmeher puts before him Indian, European, Dutch, and Gaelic clocks and observes the stars. The signs tell him that the prince will reign for seventy years; that he will be counteracted by his vizier; and that his name will be Anusherwan. When the boy grows up, Qubad Kamran wants to abdicate in favour of him, but Buzurjmehr first asks permission to educate him. The boy is entrusted to him for forty days, in which he imprisons him, beats him, and humiliates him. Afterwards Buzurjmehr offers the boy his neck to be beheaded, but the prince, thoroughly disciplined, spares him. Two years later Anusherwan accedes to the throne. After some time Anusherwan has a dream and Buzurjmehr explains to him that a hero will come from Mecca who will save the empire from its enemies. Buzurjmehr journeys to Mecca to look for him. When he finds him, he sees that 'he is destined to extract tribute from the emperors of the Seven Climes and conquer the whole world: he who would humble the great and mighty on Earth and Mount Qaf.' He calls the boy Hamza.

3 Ghalib Lakhnavi and Abdullah Bilgrami, The Adventures of Amir Hamza, trans. Musharraf Ali Farooqi (New York, 2007) 10.

4 Ibid., 6 o. 
Simultaneous with Hamza's birth, two other boys are born: Muqbil Vafadar, who will become an unsurpassed archer, and Amar, who will become a trickster full of cunning, guile, and deceit, cruel and cold-hearted. Both will be trusted and loyal friends of Hamza for the duration of his adventurous life. Hamza's birth is also noticed by Shahpal ibn Shahrukh, the great king of the jinns, sitting on Sulayman's throne and governing the realm of the peris, devs, Ghuls, shutorpas, Gaosars, Gostifils, Nim-tans, tasma-pas, Ghurmunhas, and other demons. The jinns fetch Hamza from his cradle and take him to the Qaf Mountains, where his eyes are lined with the collyrium of Sulayman. When Hamza grows up, he encounters another distinguished visitor. A veiled rider approaches him and hands him the horse of the Prophet Ishaq, named Siyah Qitas. Moreover, the strange figure - who turns out to be the archangel Gabriel-says to him:

As it is ordained by the Omnipotent One, I make you my favoured one, and pronounce this blessing that no warrior will ever overcome you, and the height of your prestige shall forever remain ascendant over your opponent's. [...] Remove that stone standing on the heap over yonder, and dig in the earth underneath. It will reveal a chest containing the arms and armour of the prophets. ${ }^{5}$

In the crypt Hamza finds the vest of Ismail (Ismael), the helmet of the Prophet Hud, the chainmail of Daud (David), the arm guard of Yusuf (Joseph), the ankle guards of the Prophet Saleh, the cummerbund and dagger of the hero Rustam, magic swords of the jinns Samsam and Qumqam of Barkhiyya, the shield of Garshasp, the mace of Sam bin Nariman, the scimitar of Sohrab (all legendary heroes), and the lance of Nuh (Noah). ${ }^{6}$

Hamza's loyal friend, the rascal Amar, is visited by the Prophet Khizr (alKhadir), who endows him with the gift that nobody will ever walk faster than he. Muqbil receives the help of the lion of God, the Exalted One, Sahib-e Hal Ata, the Feller of Khaibar's Fort, the Second of the Five Holies (Qur'an 76:8), that is, Ali ibn Abi Talib, the cousin of the prophet and the fourth caliph. During his first expeditions to defeat rebellious kings, Hamza meets a number of rulers and robbers, whom he converts to the true faith and who join his entourage. One of them is the Rabelaisian giant Adi Madi-Karib, who has an enormous, massive arse, and devours twenty-one camels in the morning, twenty-one deer

5 Ibid., 89 .

6 Ibid. 
and twenty-one sheep in the afternoon, washed down with twenty-one flacons of wine, and twenty-one camels, twenty-one deer, sheep, and buffaloes, with bread, in the evening. Adi will become Hamza's loyal, albeit somewhat uncouth and recalcitrant, friend.

In the meantime, the Persian Empire is attacked by a foreign army. The Persians are defeated, and the enemy advances towards Mecca. Hamza confronts their commander Hashsham, and, after shouting 'None but God alone is powerful!, he smashes his cranium into splinters. Hamza writes a letter to Anusherwan, to offer his help in restoring the Persian throne, but it is intercepted by Bakhtak, who through falsifying the correspondence creates enmity between the emperor and Hamza. However, Buzurjmehr intervenes. He contrives a dragon-shaped standard, which, when the wind blows into it, produces the yell 'O Sahibqiran!', meaning, 'O Lord of the Auspicious Planetary Conjunction!', which was once the epithet of Alexander the Great. He presents it to Hamza, with a tent that belonged to Danyal and that gives protection against sorcery. Amar receives a costume of trickery, hiding 444 objects, along with a cloth to cover his testicles, daggers, false whiskers, a naphta flask, a blend of medicinal potions, lip balm, a fly whisk, and a deadly sword. He is taught twelve musical styles and some songs and receives the titles Father of Racers, Lord of Mischief-Mongers of the World, and King of Dagger-Throwing Tricksters.

Thereupon Hamza and his followers advance towards Ctesiphon-Hamza combatting a lion on the way - while the Persians quiver in fear. Hamza, still a beardless but beautiful lad of sixteen, dramatically enters the royal hall:

Amir Hamza bore on his head the Throne of Kai-Khusrau, which the hell-bound Hashsham had plundered from Ctesiphon, and submitted it into the emperor's presence, along with the crown and other regalia of the empire. Amir had borne the throne on his head because when Emperor Kai-Khusrau had vanquished Turan and then occupied Iran, to render homage to the emperor, Rustam bin Zal had walked thirty steps bearing the throne on his head. In like manner Amir showed regard for Naushervan by carrying the throne on his head for forty stepssporting it like the aigrette in his turban- to declare that he was ten times more powerful than Rustam, the champion Warrior of the World, and the Reigning Lord of the Powers of Time. ${ }^{7}$

7 Ibid., 136. 
Subsequently, he seats himself on the chair of Rustam, next to the throne, while 'a shaft of grief pierced the hearts of the Sassanids' because of his boldness. ${ }^{8}$

Inevitably, one day, Princess Mehr-Nigar, daughter of Anusherwan and a Chinese princess, observes Hamza while he is bathing, and falls in love with him. He also falls in love with her and secretly steals into her bedroom. The two start courting each other, and Hamza teaches her the 'vow of fidelity to the One God and the Act of Faith. ${ }^{9} \mathrm{He}$ asks her hand from Anusherwan, but the emperor, fearing his might, promises his daughter in marriage to whoever brings the rebellious Indian King Landhoor as a prisoner before him. Hamza immediately embarks for Ceylon, but Amar fears the jinns and magic of India, and the dangerous seas. Amar subsequently experiences some miraculous sea adventures resembling those of Sindbad of the Sea in the Thousand and one nights (the 'old man of the sea', the whirlpool of Alexander). From Khizr he receives the Timbal of Sikander (Alexander), as a present for the Sahibqiran. Meanwhile, Hamza has some strange experiences, too. He is presented with magical objects by prophetical figures-including Muhammad-and is allowed the wish that he will die only after he has asked three times for it. In a dream he receives a code of conduct, including the rules: never start a fight himself, never kill a noble soul, never pursue a fleeing enemy, always offer reprieve to one who asks for it, never turn a mendicant from his door, weed out infidelity, and never be an instrument of hurt for the poor and the weak. ${ }^{10}$

Hamza is now fully equipped to perform his exploits. His expeditions in the service of Anusherwan take him to India, Egypt, Syria, Turkey, and Greece, where he either defeats evil enemies, or, more frequently, persuades the rulers to embrace the true faith and join his troops. The kings of India and China, in particular, become his faithful allies. He is helped by the endless tricks of Amar, who, moreover, speaks Arabic, Persian, Turkish, Kashmiri, Pashto, Maghrebi, Ethiopian, Zanzibarian, English, Portuguese, French, Russian, Latin, Greek, Hindi, Karnataki, Bhojpuri, Deccani, Chinese, Tartar, Rangari, and Sindhi, apart from the special trickster-language of the Ayyar, the community of tricksters and rogues. Hamza is obstructed by Bakhtak, who feeds the suspicions of Anusherwan, but each time he is saved by Buzurjmehr, who at some point turns out to have accepted the true faith. The marriage between Hamza and Mehr-Nigar keeps being postponed, either because of Bakhtak's intrigues or

$\begin{array}{ll}8 & \text { Ibid., 140. } \\ 9 & \text { Ibid., 193. } \\ 10 & \text { Ibid., 233. }\end{array}$


after oaths by Hamza not to marry her before he has fulfilled some task. In the end Hamza abducts her from Ctesiphon and sends her to Mecca.

In a long intermezzo, Hamza is magically transported to Mount Qaf to help King Shahpal in his struggle against rebellious jinns. Here, too, Hamza proves his invincibility by defeating ferocious ghouls and fearsome monsters and, above all, by neutralizing all kinds of talismans and enchantments. These are specially designed to delay his return to the human world, because Princess Aasman peri has become enamoured of him. The story provides a colourful array of miraculous elements and references to the legends of Sulayman and the jinns. Finally, Hamza succeeds in escaping from the realm of the jinns by flying over the Seven Seas on the back of the bird Simurgh and hanging from the claws of the bird Rukh. He is shown thirty-nine of the Forty Wonders of Sulayman, but he disobediently opens the fortieth door as well. In the many years of Hamza's absence, Amar protects Mehr-Nigar against Hamza's many enemies and uses all his tricks to hold out until Hamza's return. In some threatening situation he is saved by a mysterious, veiled, figure, who turns out to be a peri. After Hamza's return he hears from Buzurjmehr about the birth of the prophet. He travels to Mecca to kiss the feet of Muhammad and to offer him his service, as a warrior in his army. Finally, he is decapitated by Hind.

This summary shows that the story of Hamza neatly conforms to the generic type sketched above and even includes motifs from other genres discussed in previous chapters. First, the story starts with a play between disruption and continuity, focused on the figure of the vizier and referring emphatically to forms of esoteric knowledge, in a way that shows affinity with the material of the story of the 'Queen of the Serpents', discussed above. The introduction not only emphasizes the necessity of continuing an ancient tradition; it also outlines the main theme of the narrative, the emergence of the forces of good and evil, juxtaposed in continuous competition to steer the course of events. This clear division of roles predicts a rather emblematic set of characters, and, in fact, Hamza shows no signs of psychological depth or development; at sixteen he is already the fully grown, invincible, hero that he will remain until the end of the story. The other characters, too, are enacting their prescribed roles within the labyrinth of events, revealing a form of evolution only when they, impressed by Hamza's prowess, embrace the true faith. There is a continuous parade of villains and heroes, fighting each other with various means, drawing all kinds of motifs and narrative material into the story as if it were their only function.

Hamza's emblematic role is completely absorbed by his function as trailblazer for the prophet and the spread of the faith. Although the story is set before the advent of the prophet, it is already filled with elements of Islam, 
from the shahada to prayer and ablution, from references to the Qur'an (the fatiha) to the notion of conversion, the Oneness of God, and other doctrines. On top of that, Hamza is visited by Gabriel, granting him almost prophetic status. Ali even appears before Muqbil before he is born. These elements are not only inspired by the narrative conventions that require the story to be infused with some pre-established ideological concept; they also indicate the essential timelessness of God's message and its connection with the time-bound nature of human life. God's scheme already exists, but its earthly manifestation still has to unfold. Still, whatever happens is part of a larger, even transcendental plan. This is shown, too, by the symbolic attributes that Hamza receives and that render him into one of the few chosen heroes to be instrumental in the realization of God's plan.

As in the case of Tirant, Hamza's religious connotations are contrasted to those of his opponents. The introduction of the narrative shows how the Sassanid court is steeped in ancient wisdom, science, and philosophy, but it is still clinging to false beliefs and superstition. Whereas Hamza already swears by the one God, Anusherwan makes 'a gratuitous prostration to his one hundred and seventy-five gods.' ${ }^{11} \mathrm{He}$ and others are used to invoke, rather implausibly, the goddesses al-Lat and al-Manat, who were venerated in Mecca in pre-Islamic times and who were emphatically denounced by Muhammad. Furthermore, the Persians are Fire-worshippers who swear by the fire temple of Namrud. In a period of adversity, Anusherwan even abdicates the throne and retires to a fire temple to perform humble services to the 'idols' there. Hamza repeatedly summons him to accept the true faith, but Anusherwan refuses to relinquish the traditions of the dynasty and only in the very end does he concede to convert.

Religion is thus a clear identity marker delimiting communities and defining cultural and political boundaries. Anusherwan explicitly links religious matters with the interests of the dynasty, and when Hamza is courting Mehr-Nigar, her nanny cautions her: 'Many Sassanid and Kianid princes have sought your hand in marriage. This is a follower of the True Faith, someone who shares neither your faith nor your language. In my view it is improper for you to attach and tie yourself to him!'12 Bakhtak, the wicked vizier, agrees with her: 'Emperor of the Seven Climes was loath to marry his daughter to Hamza, and those who heard it agreed that indeed the emperor could not have given his daughter in marriage to someone who did not speak the same language and who worshipped an

\footnotetext{
11 Ibid., 141.

12 Ibid., 184.
} 
invisible God.'13 Obviously, cultural and religious boundaries reinforce one another and are related to the political stability of the empire. When Hamza advances to Ctesiphon to restore the Persian throne after the setback against Hashsham, the Persians are afraid: 'These Arabs are a most rebellious lot and show great ambitions and giddiness of mind. ${ }^{14}$ They fear a revolt with a clear ethnic component. It is evident that when Hamza theatrically carries in the throne and seats himself on Rustam's chair, the Persians consider this gesture as a humiliation and an act of sedition.

There is one force that can overcome all these boundaries and demarcations, and that is the irresistible spread of the true faith by Hamza's efforts, even before it was revealed. Hamza's expeditions in East and West show how ethnic and cultural differences are irrelevant for the adoption of the faith and for becoming an ally fighting for the lofty cause. Only Anusherwan remains obstinate until the end. The role of Hamza as an instrument of God is visible in his title Sahibqiran, 'Lord of the Auspicious Conjunction', that is, between Jupiter and Venus. It was an epithet associated with the great conqueror Alexander the Great taken on by the Mughal emperors of India. It is not only an honorary title for a conqueror or a warrior, but has millenary associations, too, as the figure whose destiny is linked to the cosmic forces and who is sent as a messiah to change the course of history. The Mughals used these elements to construct an image of themselves as the initiators of a new era and visionaries in touch with mystical and esoteric forces. ${ }^{15}$ Hamza, too, is endowed with these powers to fulfil his task: ushering in a new era in human history.

The ideological connotations of the title Sahibqiran are perhaps somewhat paradoxical, since they would not easily harmonize with orthodox visions of the faith. As Moin argues in his study of Mughal kingship, they are rather rooted in the interface between official ideology and popular beliefs, creating a common ground for the framing of power and authority in the popular imagination. This is confirmed by the other symbolic elements in Hamza's image: his being chosen by Gabriel; his paraphernalia, such as the prophets' weapons and the magical horse; his connections with earlier prophets and heroes, etc. All these elements are part of religious and historical mythology, which have become part of popular lore. Likewise, there seems to be a contradiction in Hamza's acceptance of all the magical paraphernalia and his aversion to sorcery: 'I am the mortal foe of sorcery, cannibalism and infidels, and was born to

\footnotetext{
13 Ibid., 3 O4.

14 Ibid., 125.

15 See Moin, The Millennial Sovereign.
} 
crush their vanity into the dust.' ${ }^{\prime 6}$ Clearly, sorcerers rank among the quintessential barbarians and villains, but apparently there is a 'good' magic relating to the faith. When Hamza finds a book of magic, he destroys it, but Amar, the arch rascal, tears out a few pages; that is how sorcery spread throughout the world.

Hamza's disdain for sorcery does not prevent the narrator from inserting many supernatural episodes into his tale. In addition to the religious paraphernalia, these include, first of all, Hamza's adventures on Mount Qaf, part of the lore of the Prophet Sulayman, filled with magical landscapes, enchantments, monsters, metamorphoses, the compression of space and time, the emergence of mythical creatures, miraculous rescues, astrological signs, dreams, etc. These motifs are meant to incorporate the narrative into the tradition of mythology and legend, which is represented, in particular, by the figure of Jamasp, the Persian sage, and Sulayman, the king-prophet of the jinns and the natural phenomena, but also by Danyal, the guardian of esoteric sciences. The convergence of these traditions in the figure of Hamza enhances the ideological significance of the narrative, as a medium attracting elementary material, but it also construes Hamza as a symbolic character. It is also, to be sure, part of the generic conventions that govern this type of narrative; it serves as a repository of narrative material, which is thus transmitted to future generations. It is also, of course, included because it is a great source of entertainment: the world is full of wonders and strange phenomena. In this sense it is not surprising that the story contains many motifs and episodes that can also be found in the later versions of the Thousand and one nights, such as the stories of 'Sindbad', the 'City of Brass', 'Janshah' and others: they have similar functions and draw on the same reservoirs of narrative material.

It is these generic characteristics that are conducive to the narrative's ideological function. It is its hybridity between genres, between popular lore and imperial discourse, between religious history and legend that makes it such a powerful instrument for the construction of ideological discourses, or, perhaps more correctly, for ideological discourses to penetrate it and through it reach the popular imagination. As Moin explains, the work of holy men, storytellers, astrologers, and physicians produces 'key nodes of social knowledge and opinion formation', forms of 'affective knowledge, a window into local idioms of thought and opinion'. It creates 'spheres of autonomy within the polity', which put a check on the ruler's authority. Their 'strange' forms of knowledgedivination, dream interpretation, astrology, apocalyptic verse, morality tales, 
miracle stories, edifying epics, do not fit into respectable categories of religion or politics, but play 'an important role in the dissemination of political messages and news as well as in the formation of social memory'. ${ }^{17}$

But how are kingship and authority represented in the Hamzanama? In addition to the paradoxes mentioned above, it is paradoxical, too, that the narrative offers no picture of a Muslim king or of kingship in Islam. Whereas the story is meant to show the irresistible force of the new faith, the portrayal of kingship is bound to pre-Islamic times; when Anusherwan finally converts, the story comes to a close, and the reader is not informed about the nature of kingship henceforth. This may suggest a measure of uncertainty about what a Muslim king should look like and what Muslim rule exactly implies, resulting in a rather unsatisfactory compromise, a synthesis between ancient Persian kingship and the true faith. It may also indicate the essentially Asian setting of the story, in which the tradition of kingship is primarily Persian, to which an Islamic component is added. This latter supposition is confirmed by the conspicuous syncretism of the story, which is in line with the arguments of Moin concerning the amalgamation of Sunnite, Alid, esoteric, historical, and legendary elements into a newly forged cultural identity as a basis for royal authority.

A second observation is that the logic of the story is not built around the figure of the king as the most prominent protagonist, but around the herowarrior. This narrative 'appropriation' of the central role is nicely played out in the story itself, in the tension between characters who represent different components of the structure of power: the king embodies an ancient dynasty, which is legitimized by history, by cosmic mechanisms, by the practice of just rule, and by the hierarchic organization; the hero, in contrast, has as his only legitimacy his physical force, his courage, his ingenuity, and, of course, his impersonation of a new vision, not yet sanctioned by tradition or history, nor, for that matter, by a proper revelation. The tension emerges because the two components' complementarity becomes acute: the empire is becoming weak; it is dissipated by internal strife and subdued by external forces. The symbol of this exhaustion is the stealing of the throne: the soul of the empire is torn out by irreverent villains who have no consideration for age-old traditions. The empire is on the verge of becoming obsolete and disappearing into the folds of history. In contrast, Hamza represents force and vitality, the charisma of a youthful faith, and a vision of the future. It seems only natural that these two extremes should be drawn to each other and somehow converge. This 
juxtaposition resembles Tirant's relationship with the Byzantine Emperor: he too is destined to imbue the empire with new vitality and a new lease on life. $\mathrm{He}$, too, personifies the virtues that should be at the core of the empire and that should ensure a new, reinvigorated, rule.

Still, there is no reason to assume that a convergence between tradition, cultural and historical identity, weakness, and rejuvenation combined with a new vigorous worldview would be realized smoothly. After all, it touches upon the very basis of power and authority and the question of how power and authority can be moulded into a single ideological and societal whole. From the beginning, Anusherwan fears Hamza's power, which is expressed in his physical strength, his boldness, his charisma, and the autonomy of his war band. He is afraid that Hamza will usurp the throne and destroy the dynasty, and he is supported in this by his vizier Bakhtak. He is afraid that his traditional legitimacy cannot withstand Hamza's very practical power. Hamza, however, professes his loyalty to the emperor and sets out to restore his authority in all corners of the empire. Paradoxically, however, by doing this, by subduing refractory kings, he actually undermines the empire and increases his own power, because everywhere he adds new converts to the community of believers and builds new alliances with powerful kings. While buttressing the throne he is actually weakening the position of the emperor, because the latter stubbornly holds on to his old, obsolete, religion.

Although Hamza's power is steadily increasing, he remains loyal to the legitimate emperor. Repeatedly he declares his obedience: 'I am fully obedient to your commands, and regardless of everything am still faithful to you with all my heart and soul. ${ }^{18}$ And: 'Even though I have received nothing but harm from Naushervan's hands, I will continue to return his deeds with kindness.' ${ }^{19}$ These statements are not merely expressions of generosity, as a virtue connected with the new faith; they also indicate that Hamza has no intention to topple Anusherwan and to ascend the throne himself. On the contrary, apart from a brief episode when the son of Hamza and Mehr-Nigar is put on the throne, Hamza insists that Anusherwan remain emperor, and he even retrieves him when he has retired to a fire temple. Hamza wants Anusherwan to convert to the true faith, in his capacity of emperor: 'If you swear to renounce fire worship and hold God as unique and alone, and consider the faith of Ibrahim the True Faith, I will kill these attendants and destroy the fire temple. I will settle you on the throne and make all of them show obedience to you. ${ }^{20}$ Only

18 Lakhnavi and Bilgrami, The Adventures of Amir Hamza, 303 .
19 Ibid., 753.
$20 \quad$ Ibid., 822. 
in this way can the two components of power be joined and can a new form of authority be created; only in this way can the split character of Anusherwan and, consequently, the empire, be healed; only in this way can the old tradition of kingship be impregnated with Islam and be rejuvenated as the stable foundation of a new phase in history.

As in Tirant and the texts discussed in the previous chapters, in the Hamzanama, too, we encounter once again the composite nature of authority, which comprises the prince, the vizier, the warrior, and, to a lesser degree, women. Before power can be effectively transformed into authority all these components need somehow to be balanced. The king personifies the tradition, the sacredness of kingship, the moral quality of kingship, and the anchoring of law. He represents, one might say, the essence of power. But this essence, as an ahistorical element, is not always able to deal with specific circumstances, or historical change. He is in need of viziers and heroes not only to effectuate his power, but also to enframe his power and tailor it to deal with a specific situation. Ideally, all these components are in harmony; if some disharmony occurs, for whatever reason, a new equilibrium must be sought. And, of course, a narrative must be constructed that both thoroughly examines the deficiencies and merits of the old order and justifies the establishment of a new order. In this way it not only shows how tensions are resolved; it actually contributes to an acquiescent view of reality.

\section{The Emperor and the Barbarians: The Exploits of Yue Fei}

In the Chinese imperial tradition, the position of the emperor is anchored in the cosmic configuration determined by the balance between the forces of Yin and Yang. On earth there are mainly two factors in which this balance becomes visible: the moral stature of the emperor; and the loyalty and integrity of the ministers. As indicated above, when Yang is dominant harmony rules, the empire is united and prospers, the government is effective, and the enemies keep a distance; when Yin is dominant, however, the economy collapses, strife and corruption paralyse the government, the empire falls apart, and-the ultimate disaster - the barbarians invade. History is the alternation of these (un)balances, in which harmony and dissent, prosperity and poverty, unity and fragmentation, virtue and corruption, and ultimately order and chaos seek predominance. In this conceptualization of history, 'evil' is often projected on the northern barbarians, the Mongol and Manchu nomads and their respective empires. On several occasions the tribes from the north invaded the empire and succeeded in conquering the throne and founding their own 'foreign' dynasties in China. 
Among the great wars against the barbarians in Chinese history was the invasion of the Jin Tartars from modern Manchuria, which ended the reign of the Northern Song dynasty in 1126. This struggle is the subject of the short novel Proclaiming harmony discussed above, and of a novel which will be analysed presently and which centres around the famous Song general Yue Fei (11031141), who gained his reputation in the protracted war against the Jin between 1069-1126. The novel was written by Qian Cai, who lived during the reign of Qing Emperors Kangxi and Yongzheng between 1662 and 1735 . He is part of the great revival of Chinese literature during the Ming and Qing periods, which is marked by a recompilation of narrative material, from both popular and historiographic sources, a spirit of enlightenment, and a combination of realist and supernatural frameworks. Qian Cai's book is different in the sense that it is a heroic romance rather than a novel of the type of the Dream of the red chamber, or The sorcerer's revolt, or Creation of the gods. It should be noted that the adventures of Yue Fei have become part of an extensive corpus of romantic/heroic popular literature, which moved far away from its historic framework. Qian Cai's vision is rather frugal in this respect, in spite of its hagiographical tone, and is relatively free of supernatural and fantastic excursions. It can be seen as the austere core of a more romanticized repertoire of heroic lore.

The outline of the story of the fall of the Northern Song has already been sketched above. The novel General Yue Fei begins with a reference to the Tang dynasty (618-907), which fell apart after a period of unrest, to be succeeded by the Great Song dynasty, which ruled for 300 years from its capital Bian Lang. The illustrious Emperor Huizong, as he is named here, became, as he aged, more and more immersed in Taoism, preferring spiritual contemplation over the affairs of the state. At that time a holy man arrives at the gate of a village where a son has just been born. He foretells a glorious future for the boy, but warns the parents that if a great shock occurs, mother and child should climb into a specific vessel. Not long afterwards, the child starts to scream. He and his mother are put in the vessel, and immediately a thunderstorm breaks out flooding and destroying the whole village. The vessel with the child and his mother is carried away by the teeming water until it is found by a squire who has had a dream that he would meet a nobleman that day. He adopts the mother and child into his own family.

The young Yue Fei turns out to be an intelligent, assiduous, and obedient child, who excels in writing essays. The scholar Zhou Tong notices his extraordinary talents and adopts him as a son, teaching him the arts of war. One day master and pupil go to the Hill of Dripping Water, where Yue Fei kills a snake in a cascade. A mist appears, and the snake flies in his direction, but when he 
seizes it, it turns into a spear: the Supernatural Spear of Dripping Water. Apparently, the cascade was miraculous and divine. Zhou Tong teaches Yue Fei how to handle the bow and has military attire made for him. Yue Fei is engaged to the daughter of a magistrate and now receives the title lord'. He is presented with an indomitable horse, which can only be tamed by him, as if it had been destined for him. Zhou Tong dies and is buried on the Hill of Dripping Water, in accordance with his wish, while hymns were sung by Buddhist and Taoist priests.

Gradually, Yue Fei is sufficiently prepared to undergo the military examination. He has formed a band of loyal young warriors from the squires of his town, among whom is Nin Gao, a rather coarse and impulsive outlaw. The group goes to the Eastern Capital for the examination, where Yue Fei is a candidate for the most prominent position. However, to his dismay a corrupt prince participates who has bribed four of the five examiners. In the meantime Yue Fei acquires a sword made long ago, waiting to be collected by its predestined owner, that is able to fly up and kill men by itself. There is a mysterious story connected with the sword, involving a child's head, which was boiled to produce the pill of longevity, and a priest who beheads himself. It appears that Yue Fei is the warrior chosen by destiny to carry the sword. During the examination, in which Yue Fei shows his phenomenal skills, a quarrel breaks out between him and the evil prince. They agree to fight each other and draw up a document stating that if one of them is killed during their duel, the other is not answerable for his death. Of course, Yue Fei kills the prince, and he and his group flee the examination ground.

The incident is reported to the emperor. Examiner Zhong, the one who was not bribed by the prince and who protects Yue Fei, is discharged, but he pledges to Yue Fei that he will support him whenever possible. This opportunity arrives when Zhong is called back to the capital to take charge of a campaign against rebellious brigands. He introduces Yue Fei to the emperor, but because he has slain the prince and because of the intrigues of malignant officials, Yue Fei is awarded only a minor rank. Like many other good officials, Yue Fei, offended, withdraws to his hometown, and his comrades desert him to become brigands and robbers. The emperor, increasingly absorbed in his religious musings, abdicates and puts his son Qing Zhong on the throne.

Meanwhile, the threats on the northern border are building up. In the capital city of the Yellow Dragon, the chiefs of the Great Jin, a Jurchen dynasty, are scheming to invade China. A military advisor argues:

Old southern barbarian emperor has conceded his throne to the young emperor called Qing Zhong. Since he has ascended the throne, this young 
emperor has never concerned himself with the government of his nation, but instead leaves it to corrupt officials to manage affairs, and demotes or banishes those who are loyal and good. Not only this, there are no good people to guard the border passes. ${ }^{21}$

The chances for a successful expedition seem auspicious. The ninth prince of Jin, Wushu, is nominated Commander-in-Chief to Exterminate China, because he is the only one who can lift an iron dragon. Through a combination of violence and persuasion, and in spite of the fierce resistance of provincial governors, Wushu gradually advances on the Song capital. The emperor fears for his life, the army commanders are incompetent, and the talented officials have resigned. Prime Minister Zhang, a creepy intriguer, proposes to conclude a peace treaty. He sends gold, silver, brocade, pretty girls, singing boys, pigs, sheep, cows, and wine to Wushu, who, however, demands in addition the two emperors and the crown prince as hostages, and the ancestral tablets of the previous five emperors. The royal family is subsequently led away to the north in humiliating and distressing circumstances, which are related in detail in the novel Proclaiming harmony discussed above.

In his captivity, the emperor writes an edict with his blood to the crown prince ordering him to escape and found the empire anew, so as to continue the ancestral worshipping of the previous emperors. The crown prince, Prince Kang, succeeds in escaping, helped by a magical bird, a Taoist priest, and a miraculous earthenware horse. He establishes himself in Nanjing as the Emperor Gao Zhong and attempts to regroup the Song ministers and troops. Zhang now counterfeits an edict of the emperor to call Yue Fei to the new capital, where he is accused of conspiring against the emperor's life. He is imprisoned, but his former friends hear of his ordeal and jointly advance on the capital to liberate their leader. Zhang's conspiracy is discovered, and Yue Fei is appointed Vice-Commander-in-Chief of the imperial army and later Commander-in-Chief, with the task of repelling the Jin army. Yue Fei's career is now in full bloom:

He wore a silver helmet and a suit of armour made of silver leaves, beneath which was a robe of white silk. He was astride the White Dragon Horse, and in his hand was the Spear of Dripping Water. His face was white and long, with thin whiskers and beard; his shoulders broad and waist thick, and his martial dignity was indeed awesome. [...] His manner was stern and majestic, and his murderous air was steaming. ${ }^{22}$

21 Qian Cai, General Yue Fei, trans. T.L. Yang (Hong Kong, 1995) 170.

22 Ibid., 300. 
In spite of Yue Fei's efforts, the Jin march towards Nanjing, and the emperor, who has been feasting and drinking with his concubine Lotus Fragrance, has to flee ignominiously. With the help of a magical ship they reach Oxhead Hill, where they fortify themselves against the enemy. At first Yue Fei despairs and wants to cut off his own head: 'Even in ancient times it was said that if the king was humiliated then the official should die. Now I do not know where the Sacred One is taking refuge. As a subject official, what do I have to live for?'23 But soon he recomposes himself and organizes the defences and a proto-palace: 'Pray erect a platform on the left of the Hall of Divine Officials to emulate the manner in which Emperor Gao Zu of the Han Dynasty appointed the generals. You should ceremoniously make the appointments of the Commander-in-Chief and all the military officers so that they will be willing to sacrifice themselves for the country.' ${ }^{24}$ Yue Fei prepares for battle: 'Tomorrow the Sacred One may mount the platform to watch the battle between me and Wushu. General Wang will please report over merits, and the Grand Counsellor will please record them in the Credits Register.'25

The battles end in a stalemate, and Wushu proposes a peace agreement. The emperor concedes and re-ascends the Great Precious Throne. Yue Fei retires to his village, embittered by the weakness of the emperor. The empress embroiders a pair of banners for him, showing a phoenix and a dragon, and the words 'serving the Nation with the utmost loyalty'. ${ }^{26}$ Yue Fei returns to the court, but he is accused of rebellion and in the end is strangled to death, together with his son, in spite of his lament: 'Throughout my life I have but one ambition, and this is to restore China and to wipe away national humiliation. ${ }^{27}$ His death does not pass by unnoticed: 'When [they] returned to Heaven, suddenly a fierce wind rose up wildly and all the fires and lights were extinguished. Black mists filled the sky and sand and pebbles were blown about. ${ }^{28}$ Moreover, our hero has his revenge posthumously, as his spirit enters someone else's body, who appears before the emperor calling himself Yue Fei. The emperor, struck by fear, falls from the Dragon Throne and dies. The next emperor restores Yue Fei's honour, and his family returns to its former illustrious status.

In this summary of Yue Fei we find some familiar elements that we have seen in the other romances, but there are important differences as well. Whereas

\begin{tabular}{ll}
\hline 23 & Ibid., 436. \\
24 & Ibid., 439. \\
25 & Ibid., 457. \\
26 & Ibid., 540. \\
27 & Ibid., 703. \\
28 & Ibid., 721.
\end{tabular}


Tirant and Hamzanama are clearly chivalric romances, in spite of novelistic elements in the former work, the book of Yue Fei can be more accurately typified as a historical novel. Not only are the main characters all historical figures; the realistic, historical, framework also infuses the spatio-temporal structure of the narrative. The story takes place within a geographical and historical reality, which is amplified by the many references to formalities and procedures such as the description of the military examination, the reports sent by officials, registrations, legal documents, etc. It will be recalled that in Tirant, too, the exploits of the hero are embedded in procedures and agreements, but in Yue Fei, as in other Chinese novels, the strict adherence to formal rules and regulations is even more pronounced. When the wife of Prime Minister Zhang helps the emperor escape from the vicious schemes of her husband, she convincingly argues: "This concerns the great issue of loyalty of an official to the Emperor. Will this not entirely destroy human relationships?'29 After she has helped the emperor flee, she commits suicide, as the prescriptions demand. On Oxhead Hill the ceremonial structure is provisionally reinstated.

The realism of the story is also reflected in the sparing use of supernatural elements. Of course, Yue Fei is blessed by a miraculous rescue as an infant, and with a miraculous horse, spear, and sword, but these attributes only enhance his symbolic status, as a warrior predestined within history and within the cosmic balance of forces. They are at no point used to defeat enemies in magical ways or miraculously decide a battle, and seem to be paraphernalia rather than weapons. In contrast, other 'miraculous' weapons are more elaborately described and used, such as gunpowder and cannon, and the ingenious battleships of the brigands on the lake. Supernatural phenomena are more generally apportioned to the Song Dynasty, and more specifically to Prince Kang, whose escape from captivity is clearly due to the efforts of the immortals. Religion is hardly an issue, in spite of the appearance of the odd Buddhist or Taoist priest, or references to ancestral worship. All this contrasts sharply with, for instance, novels such as Creation of the gods, or The war of the three kingdoms.

Although these novelistic elements distinguish Yue Fei from the genuine epic, it cannot be said that Yue Fei as a character has novelistic traits. Perhaps to emphasize his heroic role, as a knight of the old tradition, Yue Fei escapes from his emblematic role, which highlights his unwavering loyalty to the Song Dynasty. Even when his talents are spurned, he refuses to give up his loyalty: 'I was born a subject of the Song Dynasty, so I should die a ghost of the Song 


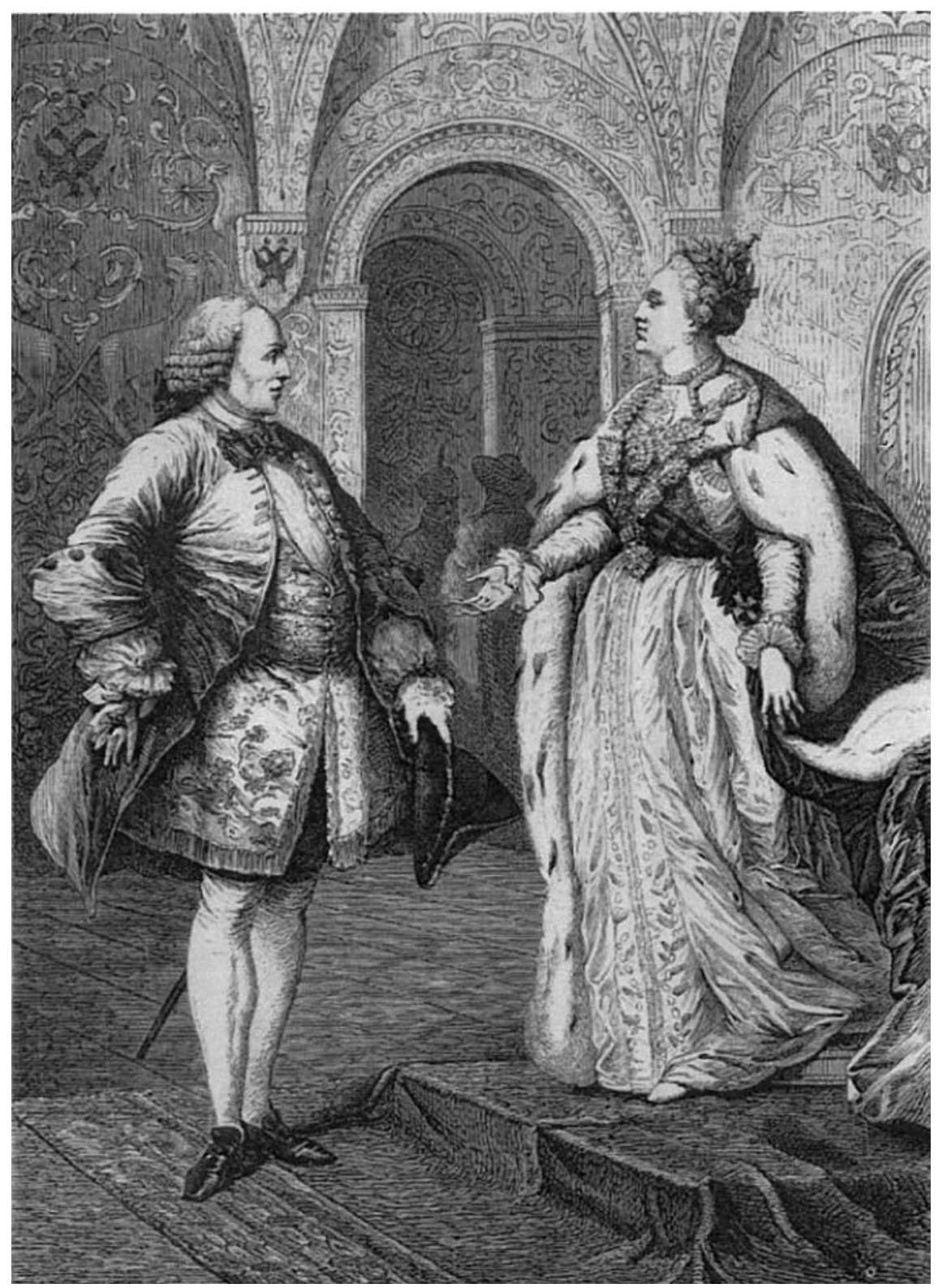

FIGURE 6 Diderot and Catherine II, by Alphonse Marie de Neuville, 19th century. 
Dynasty. ${ }^{30}$ To emphasize this devotion, he has a tattoo applied to his back: 'Serving the Nation in the utmost loyalty'. ${ }^{11} \mathrm{He}$ is prepared to kill himself and his son as a punishment for negligence in serving the throne, and is only prevented from doing so by others, and when he is accused of rebellion he only repeats his testimony of utmost loyalty. This loyalty carries over to the bond between the members of his warband, who are loyal until the end to their chief, not only rescuing him when needed, but also sacrificing all their strength and courage to the good cause. Like Tirant and Hamza, he is therefore a kind of saviour, a charismatic hero destined to influence the course of history, but unlike them, he is unable to mould history to his will, and in the end 'real' history curbs his ambitions.

Yue Fei's loyalty and charisma are primarily directed at the dynasty, represented, first, by the old emperor and subsequently by his son and Crown Prince Kang. It is the position of the emperor and the continuity of the dynasty that have to be defended, rather than the emperors as persons. This does not mean, however, that there are no other identity markers and conceptualized relationships. Throughout the work the notion of China, as an ethnic, historical, and political entity, is evoked, for instance by a governor who meditates, after an offer by Wushu: 'I am Chinese. My ancestors and all those related to me by marriage are in China, so how can I accept fortune and prestige from you?'32 Interestingly, Wushu is portrayed as a sinophile who is 'addicted' to Chinese literature and history; who loves the Chinese people and often wears Chinese clothes. ${ }^{33}$ When the long period of war ends in a stalemate, and Wushu offers peace, he apologizes for his conduct and pledges: 'China and Jin were originally one family. Your emperor and the lord of the Jin are brothers. [...] Today I shall swear an oath to Heaven: from now on we shall live in harmony and we shall never invade China. ${ }^{34}$ This is not the opinion of Yue Fei, who continues to consider the Jin as foreign invaders and barbarians, especially since they refuse to release the two emperors. In the novel, the Jin are finally defeated after seven years, and the bodies of the Song emperors and empress are brought back to their family.

This brings us to the issue of kingship. In Yue Fei we perceive a pattern similar to that in Tirant and Hamzanama. The emperor holds the legitimacy derived from the stability of the dynasty, the balance of celestial forces, and

$\begin{array}{ll}30 & \text { Ibid., 246. } \\ 31 & \text { Ibid., 248. } \\ 32 & \text { Ibid., 306. } \\ 33 & \text { Ibid., 171. } \\ 34 & \text { Ibid., 515. }\end{array}$


the integrity of his person. As soon as this delicate configuration begins to shift, weakness creeps in and foreign enemies take the opportunity to execute their wicked plans. As a counterpoise to the weakening of legitimate power, a hero emerges instilled with the forces hidden in history, allowing him to gather a de facto power based on his virtues, courage, strength, and loyalty. Thus, a crisis in the system provokes alternative powers, both good and evil, to fill up the vacuum of authority. The 'good' powers are aimed at neutralizing the 'evil' powers, but they are not automatically acknowledged by the legitimate ruler, since they seem to be a challenge to him too. The dilemma is, again, how to mould the two components of power into a single apparatus, both practically, reconciling de facto power with legitimacy, and ideologically, redefining concepts of loyalty and order. Only then can a new balance be achieved that can warrant the successful exertion of authority, the exertion of power not through force but through authority. In Yue Fei this is realized only after the death of the hero, who, anyhow, because of his unyielding loyalty, would never have accommodated to a process of historical change.

\section{Hang Tuah, the Malay Hero}

The story of Yue Fei shows how the values of kingship, and society as a whole, as part of a discursive, ideological system, can be preserved and conveyed by using historical references and reconstructing it within a fictional framework. This procedure can be used to legitimate kingship or to analyse the origins and conjure the effects of crises. History is encapsulated in a new framework, in which it can be assimilated with and be preserved in the common perception of history and society, as a repository of essential concepts that can be related to changing circumstances. These observations are especially relevant for foundation myths, which operate in the interface between history and legend, and are both a legitimation for a community and an epitome of its main values and selfimages. Whereas the romances we have discussed until now are related mainly to crises, of the Byzantine, Persian, and Chinese imperial thrones, we will now turn our attention to a narrative that belongs more properly to the category of foundation myths, although it, too, is in the end related to crisis. Therefore, perhaps it should be read not only as a foundation myth, but also as a text investigating the crises that in the end threatens the very survival of the community. It is also possible to read the text as an unfinished story, as a chronicle that has been violently interrupted.

The romance in question is the Malayan popular epic The history of Hang Tuah, which belongs to the interesting corpus of romances (hekaya or sira) 
that appeared in Malay from the fifteenth century onwards, and that presents a combination of history and legend. This particular work certainly postdates 1641, because at that date Malacca was conquered by the Dutch East India Company, the episode that concludes the work. The manuscript on which the German translation used here is based is datable to 1718 , but the text certainly contains older material, perhaps going back to the fifteenth century. The events at the beginning, after the mythical introduction, refer to the reign of Sultan Mansur Shah (1374-1447) and the reign of Sultan Alauddin (1447-1474). The work is related to the chronicle Sejara Melaya ('Malay chronicle') and other narrative sources. As we will see, the text also clearly reflects the influence of the Muslim cultural realm, both in the material itself and in titles, terminology, etc., indicating an intensive interaction with the wider Muslim world in that period, after the gradual Islamization of South East Asia from the fourteenth century onwards.

In spite of the structural link with the Muslim domain of religion and literature, it is clear from the beginning that a form of syncretism is allowed to survive in the text, suggesting that probably material from an earlier period has been incorporated into it, or, perhaps more accurately, that the Islamic parts were grafted onto earlier material. The story begins with the semi-divine origin of the later kings of Malacca. In the divine empire, Sang, a powerful ruler, has many vassals and ministers. He is venerated by all. On earth, there rules a mighty king with a miraculously beautiful daughter. Soothsayers advise the king to build a splendid palace for her on the island Biram Dewa, where she will meet her future husband. One day Sang goes hunting on Biram Dewa, finds the palace, and marries the beautiful princess. They have a son and return to the divine empire, but when the son, named Sang Peri Dewa, grows up he has to return to the earth to rule, in a palace on the holy mountain of Malaya, near Palembang. When Sang Peri Dewa goes bathing, he sees a well-built ox on the shore. It vomits a beautiful girl. Sang Peri Dewa marries her, and she bears him four sons, who will all be kings.

This introduction defines the semi-divine status of the Malaccan kings:They are humans, but they are the offspring of Dewas and Indras, of spirits and gods. When the king of the people of Bentan dies, they ask Sang to send his eldest son to rule them. A court is set up with four nobles, who act as grand vizier (Bendahara Paduka Raja), prime minister (Perdana Mentri), minister of justice and commander-in-chief (Temenggong Seri Diraja), and court menial (Tun Pikrama). After a dream in which the moon falls from the sky and creates a halo around the head of his son, the father of Hang Tuah moves to Bentan to open a shop. From his early youth, Hang Tuah is courageous and bold, and one day he and his friends go out at sea and defeat a band of pirates. They become pupils 
of the wise Adri Putra, who teaches them wisdom, martial arts, physiognomy, and the art of gestures. On their return they defeat an amok-runner and as a reward are accepted as pages of the king. Because of his intelligence, the king heeds the Hang Tuah's advice.

At a place on the shore where a small deer is seen chased by a band of dogs, a new capital named Malacca is built. The new kingdom gradually develops relations with other settlements in the archipelago, and the brothers of the king become kings of the Kling Empire, Java, and Menang Kabau. Hang Tuah teaches the young princes how to behave as kings, how to give audience to their ministers and officials, and the terms and conventions for giving commands. In the meantime, Hang Tuah distinguishes himself in several confrontations with other princes and becomes a powerful hero with the title Laksamana ('admiral'). Jealous rivals now accuse him of flirting with the palace girls. The grand vizier advises him to leave, and Hang Tuah decides to go and abduct the gorgeous daughter of the grand vizier of Indrapura, to present her to the king in marriage. When he has succeeded in bringing her to Malacca-using a potion that made her enamoured of him—he regains the king's trust: 'The words of the Laksamana were equal to the words of the king, because the ruler gave him his fullest confidence. ${ }^{35}$

A scheming rival once again accuses Hang Tuah of improper bevaviour, and the king orders Hang Tuah's execution. The grand vizier alerts him, however, and allows him to escape:

When a ruler orders me to execute you, although you are innocent, and obey his command, I will have a bad reputation among the populace, and they will say: 'Look at the grand vizier; he has executed the Laksamana without an investigation, although he was innocent.' And before God the Almighty my guilt will be great, because you are a mighty warrior and an official of the land. ${ }^{36}$

A pious sheykh predicts that his exile will last only twenty days. After the pretender has created havoc in the palace and usurped the throne, Hang Tuah returns and defeats him, restoring the king to his throne. The subsequent episodes recount Hang Tuah's adventures at sea, his visits to the Kling capital, which is a prosperous commercial centre, his journey to China, where he sees

Die Geschichte von Hang Tuah. Eine Erzählung aus dem 16. Jahrhundert über den malaiischen Volkshelden, trans. Hans Overbeck (Leipzig and Weimar, 1986) 270.

36 Ibid., 27o. 
temples and strange statues, and his journey to Siam, where he buys elephants, and finally, to Ceylon. These journeys, of course, mark Malacca's position as a flourishing centre of the South East Asian trade networks, which cover the eastern regions. On his travels he also meets the Prophet Khidlir (al-Khadir or al-Khidr), who gives him magical fruits.

The final-long-episode describes Hang Tuah's expedition to the west, that is, the Arabian Peninsula, Egypt, and Istanbul, to buy firearms and large cannon. He travels via Aceh to Mocha and Jedda, and it is explained to him that from here the Hajj-pilgrims go on to Mecca, to visit the tomb of Eve. Hang Tuah, too, wants to visit Eve's grave to obtain blessings that may be profitable in the Hereafter. He is advised to wait for the pilgrimage month and become a Hajji. While they are waiting for the pilgrimage month, they do some sightseeing and visit the tomb of Eve and other graves, and admire the treasures of Masir (Egypt) and Scham (Syria). They also meet Khidlir once again. Then they perform the ceremonies and obligations of the Hajj, to become 'Hajisi'. They subsequently visit Egypt, before gradually advancing to what is called Byzantium or Istanbul. The name 'Ottoman' is not mentioned, but it is clear that the city is considered as one of the main political centres of the world and part of a friendly empire. The city is described as enormous, with a million streets, a surface so big that after four months they have seen only one quarter of it, and with thousands of elephants. Hang Tuah receives a cap and a turban cloth from the sultan personally, as a present for the Malaccan king, and shiploads of weapons. ${ }^{37}$

When Hang Tuah returns home, he has himself buried to experience what it is like to be dead. He retires for some time to meditate on God with a sheykh from Hadramawt who came from Mecca via Aceh.

The journey to Istanbul is no mere pleasure trip, but is required by the changing circumstances in South East Asia. Already on his first journey to the Kling Empire, Hang Tuah had encountered galleys of the Franks, who shot at his boats with seven cannon. In the end the Franks surrendered, and this victory ushered in the period of Malaccan trade. The confrontations with the Franks continue and increase, however, for instance when the Malaccan ships moor at a place also used by the Franks to unload their ships. The Franks and the Malay are 'enemies from ancient times'. ${ }^{38}$ In 1571 the Spanish/Franks

37 The account of the journey to Mecca and Istanbul is derived from a description of a historical delegation from Aceh, combined with descriptive passages from Malay romances. Vladimir Braginsky, The Turkic-Turkish Theme in Traditional Malay Literature. Imagining the Other to Empower the Self (Leiden and Boston, 2015). 
conquer Manila, which is the direct occasion for the delegation to Istanbul, to the prince of Byzantium, who is 'God's substitute on earth'. ${ }^{39}$ Nevertheless, after the expedition to Istanbul, the Franks/Portuguese come with a ship filled with merchandise from Manila and request permission to build a factory next to the main gate of Malacca. This permission is refused, but the following year they are allowed to buy a small piece of land. They build a huge fort, however, from which they shell the town. Some years later the fort is conquered by the Dutch, with the help of the neighbouring Johor people, and they are 'in Malacca until the present day'40

Like the previous narratives, Hang Tuah is not about the king, but about the hero who is the mainstay of the royal throne and the effective instrument of power. The king represents legitimacy and royal descent, and incorporates a bond between the Malay people and the divine. Thus, the historical unfolding of the Malay empires is rooted in religion and myth, making its existence not only legitimate, but even unavoidable. As Laksamana, Hang Tuah acquires so much power that, as in the other cases, it is feared that he will usurp the throne, but he remains loyal to his king. He represents all the aspects of the kingdom that the king does not possess: He is courageous, he undertakes sea journeys, he defeats enemies, he is practical and ingenious, he speaks twelve languages (including Arabic and Chinese), and he is an organizer of trade. The ministers, although they are mentioned explicitly, especially the grand vizier, are depicted as fearful and weak, suitable for ceremony only and scheming, but useless in times of danger. However, even Hang Tuah cannot prevent the Franks, in their different guises, from imposing their military hegemony on Malacca and thereby penetrating the Malay trade network.

The symbiosis of the Malay king and Hang Tuah is associated with a clearly delimited political-ethnic community: the Malay people. The Malay realm is first of all defined by the four kings of divine descent, who divide power over regionally spread centres, but who unmistakably share the same cultural and ethnic identity. Surely, there is some miscegenation with other Southeast Asian peoples, especially the Javanese. During a visit to Indrapura it is remarked: 'The melodies of Indrapura are not Malay, for although we are mixed with the Malayans, we are not pure Malayans, like the people of Malacca, ${ }^{41}$ And: "The people of Malacca are Malayans who have mixed with the Javanese of Menjabalut.'42 Clearly, the regional peoples are ethnically close to each other

\footnotetext{
$39 \quad$ Ibid., $5^{22}$.

$40 \quad$ Ibid., 583 .

41 Ibid., 211-212.

42 Ibid.
} 
and mixed. They are not always friendly, however, and it is remarkable how often ceremonial visits to other courts end in rows and fighting, the host challenging the courage of the visitors and the ministers scheming to test the vigilance of Hang Tuah. There are relationships and familiarity, but they are certainly not without incidents, envy, and animosity.

As remarked above, the definition of the community is related to religious mythology affirming the divine origin of royal authority. Still, this religious component of identity is not without ambiguity. Hang Tuah's process of initiation reveals how various religious elements are combined to shape his spiritual state. He is first initiated into knowledge and wisdom by Adi Putra, a Hindu sage. His development into a hero is marked by symbols and objects of several kinds, ranging from prognostics, a magical crease which protects him, the ability to transform himself, a magic potion, a girdle with Quranic verses, a magic cudgel, several meetings with Khidlir, the Muslim al-Khadir, a formula disabling the Frankish cannon, the hajj, and finally the teachings of an Arabian Muslim sheykh and spiritual retreat. Therefore, the text contains elements from various sources, which were gathered over time, from religion, popular beliefs, popular lore, and Arab Islam. Hang Tuah seemingly develops from a Hindu disciple into a Muslim, with the hajj as the great turning point. However, the journey to Istanbul to ask for military support — which is historical-indicates that Malacca before that time identified itself as belonging to the Islamic world, with the Ottoman sultan as the symbol of political and religious unity. It is remarkable that China and India, both strong regional powers, play little role in this respect.

To conclude, Hang Tuah shows many other, by now familiar, characteristics of the romance of chivalry that we have discussed above, with some significant differences. It is a hybrid text, in the sense that it combines history with fiction and seems to be composed from various elements from diverse sources. It contains the markers defining the identity of the community, both internally (semi-divine kingship), and externally (the splendour of Mecca and Istanbul, the centres of the Muslim faith). Authority is based on the complementary balance between symbolic and effective power, represented by the king and the hero, whereby the hero, more than the king, personifies the values of the community. It is the hero, too, with whom the audience will identify, as the protagonist of a history that has been narrativized to be incorporated into the collective imagination. 


\section{The ‘Foreign' Sultan: Al-Zahir Baybars}

In Hang Tuah we can see how an epic story can serve to record the founding myth of a community, a city, and an empire. This kind of narrative tends to emphasize criteria such as authenticity, virtue, and piety, in addition to courage and enterprise. It is much more complicated when kingship —or a dynastyis not rooted in the origin of the community, or even in its history, such as the Manchu and Mongol emperors in China and Iran. In these cases it is not the identification of the ruler with the community that should be stressed, but rather the ruler's capacities, such as virtuousness, justice, and courage. It can, of course, be questioned whether an identification of the ruler with a community is a necessity for good governance, since notions of social or political coherence need not be expressed in ethnic or linguistic criteria. Power structures can be built within a society without necessarily being rooted in history, which for many people may be only a faint concept. A case in point is the Ottoman Empire, whose dominance of the Arab regions was perhaps always perceived as 'foreign' but which was contested politically only with the rise of the notion of nationalism and an Arabic cultural identity.

In this section we will briefly discuss a work that reflects these issues of identification, power formation, and literary discourse: the Sirat Baybars, or the 'Romance of Baybars'. The text is a romanticized account of the career of the famous Sultan al-Zahir Baybars al-Bunduqdari (1223?-77; r. 126o-1277), the first Mamluk sultan of Egypt and Syria and the founder of Mamluk rule (126o-1517). After the Kurdish Ayyubid warlords had pushed back the crusader kingdoms in Syria, they founded the Ayyubid dynasty in Egypt and Syria (1171-1260), forming a new Sunni stronghold against the incursions of the Franks. After their line died out, the sultanate was taken over by one of the leaders of the corps of slave troops, or mamluks, named Baybars, whose rule was acknowledged by the majority of the other commanders after a fierce power struggle. Since the Mamluks were slaves, their rule did not constitute a dynasty; succession was based on the acquisition of power within the various factions of the Mamluk amirs. Since the slave troops were Turks mainly from the Asian steppes and the Caucasus, they could not identify with Egyptian or Syrian history in any meaningful way, and the legitimation of their power consisted rather in their ability to establish internal order and to defeat the Crusaders and, later, the Mongol invaders. Apart from this, their power was entwined with an elite of spice merchants who profited from the increasingly lucrative trade with Southeast Asia.

The way in which Baybars secured his position as sultan was therefore based not on claims of historical or traditional legitimacy, but rather on his personal 
character and talents. It is perhaps for this reason that he became a figure who appealed to the popular imagination and who remained attractive for later generations, too. It is not improbable that popular stories about Baybars started to circulate not long after his death, and perhaps some accounts of his personal exploits may have been spread and cultivated during his lifetime, as part of a narrative base for legitimacy. It has also been argued that the material for the romance conforms more to the exploits of the later Sultan Barsbay. Whatever may have been the case, the 'Romance of Baybars' as it has been preserved seems to be a huge reservoir of popular stories connected with Baybars, the Crusaders, the Ismailis in the Syrian mountains, the Mongols, and the intrigues among the Mamluk emirs. It is not a straightforward biography, even as a romanticized narrative, but rather a confluence of narrative material around the person of the illustrious sultan. In this sense, it is related to many other Arabic siras/romances, but it is different, too. Whereas the heroes of most romances are legendary or semi-historical figures, Baybars lived in the full light of history; and, whereas most heroes, as we have seen, tend to support a legitimate king and embody the discourse of kingship as separated from the legitimacy of the king himself, Baybars is both the hero and the king. Here, there seems to be no separation between the components of royal authority.

Let us now turn to the romance itself. The story begins with a dream of the Ayyubid King al-Salih Ayyub, who has seen himself on a hill with his army and his noblemen, while from the east a fire is approaching and from the west two crows come flying. From the east a band of lions approaches, led by a huge animal with a bull's head, which extinguishes the fire. A flight of birds chase away the crows. The king turns to his soothsayers to ask for an explanation. They tell him that the country will be attacked by Fire-worshippers, who will be defeated by a mamluk who will inherit the throne. The crows are the Franks who will be repelled by the people from the mountains, whose leader will acquire fame in all corners of the world. After hearing this explanation, King alSalih Ayyub, who has assumed the titles of Descendant of Muhammad, Sultan of Syria and Egypt, Khaqan of the Two Seas, Servant of the Holy Places and the Aqsa Mosque, decides to purchase a new contingent of slaves to become viziers, amirs, equerries, and other functionaries. A merchant is sent to Damascus, where a new group of mamluks has arrived from Bursa, led by two commanders, Qalawun and Edamor. The mamluks are bought, but before their departure to Cairo they find a strange boy called Mahmud in a bathhouse. A fight ensues, in which Qalawun spits in the boy's face, while Edamor protects him. The boy is bought with a special purse of forty pieces of silver, which Ayyub had received when he ascended the throne. 
When the new mamluks leave Damascus, Mahmud stays behind. He is bullied by the governor of Damascus, but he shows his special destiny when he is mysteriously spared by a fierce lion and receives the prophecy that he will be king of Syria and Egypt and the 'Islamic land'.43 He spends some time in the Nur al-Din Hospital, where he becomes more self-conscious and performs good deeds for the poor. Because he looks like her deceased son Baybars, he is adopted by a prominent lady and assumes the name Baybars. The narrator now reflects on Mahmud's past: He is the descendant of a dervish and the queen of Balkh. As a boy he was intelligent and versed in the Qur'an, arousing the jealousy of his uncles. Mahmud disappeared and turned up, alone, in Damascus, bitterly disposed against his uncles. Comforted by the prophecy of his future splendour, Baybars buys a large mace that, a Persian merchant explains to him, came from Samarkand and, according to a book, would emerge in Damascus and be bought by someone who will be king of Syria, Egypt, and the lands of Islam. Baybars buys the mace and departs for Cairo, where he is welcomed by his master al-Salih Ayyub.

After some intrigues in Cairo, often instigated by the qadi, who is jealous of him, Baybars meets Uthman, a brutal, notorious rogue, who scares even the police and the governors. Baybars feels affection for him-he is a young and handsome lad, long, straight, and supple as a willow branch, with black eyes, and beardless, in brief, very attractive - and decides to adopt him as his friend. He beats and disciplines him until he is obedient and teaches him to follow God's rules. Uthman finally swears loyalty to God and Baybars, invoking The Lady, Umm Qasim, the Protrectress of Cairo, La Hasiba, or Sayyida Zaynab, the patron saint of Cairo. Baybars teaches him the doctrines and rituals of the faith, and Uthman demands that Baybars will have no secrets from him, will always tell him where he goes, will eat the same food as he, and will give him as many gold pieces as he wants. They now become brothers in the sight of God. Uthman is pardoned for his past mischief out of respect for amir Baybars.

Baybars steadily advances in the hierarchy of the Mamluk elite, enjoying the special favours of the king. He is appointed amir al-hajj, commander of the pilgrimage caravan, and flag bearer, and receives the tax farm of the sugar factory in Bulaq and the governorship of Mahalla. His destiny to become king is affirmed when the vizier shows him an alcove in which portraits are displayed of the kings of the Ayyubids, beginning with Sunqur the Atabek of Aleppo and ending with Baybars himself sitting on the Egyptian throne. This confirma-

Roman de Bä̈bars, trans. Georges Bohas and Jean-Patrick Guillaume, 10 vols. (Paris, 1985) vol. 1,84 . 
tion of the prophecy gives him the confidence to confront the many intrigues against him plotted by his rivals. In the meantime he has several mysterious experiences. First, he has a meeting with al-Khadir, who teaches him the art of war and instructs him to always let justice prevail and to inspect the conditions of his subjects. He provides him with the strength of forty righteous people of God, that is, saints. He receives seven marks of royalty on his forehead.

Another strange adventure involves Baybars reading a book in his new palace when suddenly the candles move by themselves. He hears the voice of his forefather Sultan Ibrahim and is transported to another dimension, where he is met by a giant jinn. He is summoned to draw a spear from a ring, and when he succeeds in doing so, he is given the armature of a previous inhabitant of the palace, a famous king of Egypt and warrior for the faith. A third incident takes place when he supervises the building of a bridge in Mahalla, which is destroyed every night after a day's work. Baybars encounters three saintly hajjis, whom he had seen among forty saints in the Qasyun cave in Damascus, and who explain that Baybars has failed to ask permission from the proprietor of the land, who is Sayyid Ahmad al-Badawi, the illustrious saint of Tanta, Liberator of Captives, the man with the Two Veils. Baybars is transported to a deserted plain, where he enters a mosque. A man appears with wings and a veiled face. The saint prophesies that the Franks will attack the Muslims seven times, and he gives Baybars a breastplate and a ring with which he can travel fast. Later Baybars has another meeting with Ahmad alBadawi, and this time he is allowed to see his face and 'the strong light from his eyes. ${ }^{4}$

In the following episodes Baybars is sent on an expedition in which he can show off his military skills, first to liberate Muslim captives, and later to confront an invasion by the Mongol/Persian Khan Halawun [Hülegü], who wants to take revenge for the defeat by Ayyub of his father Möngke Timour. During a duel between Baybars and Halawun the latter reveals that the Mamluk amirs are scheming against Baybars, and he offers him the throne of Persia. Baybars is now inclined to accept the offer, saying: 'I want to go to the Persians; I was born a Persian, ${ }^{45}$ but Ayyub, who has hastily come to the front, forces him to remain loyal, using even magical means. Subsequently, Baybars captures the Byzantine Emperor in Constantinople and conquers Jerusalem. Later, Baybars is abducted by the Christians and taken to Genoa, where Ayyub

44 Ibid., vol. 4, 217.

45 Ibid., vol. 5, 115 . 
retrieves him with a ship of Muslim troops. This is only the beginning of Baybars's dealings with the Franks and the Byzantine Emperor, which are mainly concerned with intrigues against his person, refractory Christians in Syria, and the ransoming of prisoners. The main actors are the treacherous monk Jawan, $b a b b$ Michael of Constantinople, rey John of Genoa, and King Frederick of Rome.

When Ayyub becomes fatally ill, he leaves no doubt that he wants Baybars to succeed him. He has him wear his ceremonial dress and take his place in the royal cavalcade. He receives a document stating that nobody may accuse him of having poisoned the king. Official bay'as - acceptances of his rule-are written by some of the amirs, the dervishes, and the sheykh of the al-Azhar Mosque. This arouses the jealousy of the rivalling amirs, especially Qalawun and Aybak, and when after Ayyub's death Baybars is declared king, the amirs protest and refuse to accept him. Thereupon Baybars declines the kingship, not because of the intrigues against him, but because he knows that there are still two princes of the Ayyubid line who precede him. Thus, two princes ascend the throne, but both are killed miserably. Baybars, who has in the meantime married Taj Bakht, the daughter of the Mongol Khan Berke, is again pronounced king, but he still refuses.

After the battle of Ayn Jalut, in which the Fire-worshippers are defeated, and after many intrigues, Baybars finally concedes, but he poses several conditions: First, that the fidawis, the warriors from the mountains who are his main support, be integrated into the regular army and paid from the state treasury; second, that all amirs become fully dedicated to the struggle against the Franks; third, that no intermarriages be allowed between the different ojaqs, or regiments (Kurds, Daylamites, Circassians, Turkomans), in order to prevent their conspiring against him; fourth, that no official can be discharged without a legally valid reason; fifth, that no assemblies of amirs occur without prior permission; sixth, that no new palaces be built without prior permission. After the amirs have ratified these conditions, Baybars is now formally and ceremonially enthroned as the next sultan of Egypt and Syria. Here the second phase of Baybars's adventures begins, consisting mainly of opposing the Christians and the Persians and countering domestic intrigues and conspiracies. Needless to say, the sultan not only overcomes all challenges to his authority; he also reveals himself to be a just and benevolent ruler.

If we look at the narrative strategies and generic characteristics of the 'Romance of Baybars', we find that it contains some elements of the 'adventure trope', but that it at the same time escapes its typical emblematic procedures. The story begins with an interruption, leaving Mahmoud/Baybars alone and forsaken in Damascus, and with a prophecy that he will at one point be 
king. The story contains many familiar motifs, such as the miraculous weapons, dreams, mystical meetings, great exploits, heroic feats, etc., filling the main protagonist with symbolic and narrative potential. Still, the story also shows a remarkable measure of realism, which is partly due to the 'real' historical framework, but also to the enactment of the intrigues, the insertion of dialogues, and the diversity of characters. This realism is enhanced by the figure of Uthman, whose role is, of course, reminiscent of Sadan in 'Ajib and Gharib', Adi Madi-Karib and Amar in Hamzanama and Nin Gao in Yue Fei, all caricatures of uncouth, impulsive hotheads endowed with unyielding loyalty. But Uthman is not only this; his defective colloquial speech, his quick repartee, and his combination of stupidity and cunning render him into a link between the audience and the hero, the person with whom the audience can identify, especially since Baybars himself is not Egyptian. Uthman is a son of the common people, who draws 'real, everyday' life into the story as a frame of reference.

These characteristics give the romance to some extent the appearance of a biographical novel in which Baybars's career and development are described in well-measured steps. It has to be said, however, that many of the intrigues and plots are rather stereotypical and represent the farcical turns of more conventional romances. Especially the Christians, as arch-enemies, are caricatures, both as despicable, treacherous schemers and plotters, with their secret books and foul rituals, and as stupid and uncivilized boors who have no understanding of protocol, law, and decent warfare. They need to be humiliated and corrected, and if they submit, they will be left in peace. The romance contains a typical love story, between Maryam, the daughter of the king of Genoa, and Ma'ruf, the leader of the fidawis. Maryam, who after an auspicious dream and after being harassed by a monk is converted to Islam, is married to Ma'ruf, who penetrates her twenty times during their wedding night. The 'victory' is described in rather martial terms: 'The outstretched weapon approached the fortified tower, which began to tremble and asked for mercy; the small door opened itself, blood flowed on the thighs and hips, the cannon took position before the breach, and the citadel surrendered itself completely. ${ }^{\prime 6}$ This brief episode is not just a colourful addition; it epitomizes the essence of both Christian and Muslim chivalric romances symbolizing both the moral triumph of the true faith and military superiority.

As observed above, one of the most intriguing aspects of the romance is the fact that Baybars is not of Egyptian origin, but from Central Asia. The figure of Uthman is, among other things, designed to symbolize the synthesis between 
Baybars and Egypt and his integration into the Egyptian popular milieu. Still, his foreign descent is emphasized several times. When he arrives in Cairo he is unable to understand the Egyptian dialect; he is called a 'Turk' and 'Baybars of Khwarazm', emphasizing his foreignness. In his confrontation with Halawun he is even tempted to defect to the Persians, in spite of their being characterized as Fire-worshippers. He 'feels' Persian, and seems to have landed in Egypt not out of free will, but only as a result of the betrayal of his uncles. He feels homesick and longs for his mother, brother, and sister. And, finally, he marries a Mongol princess, forfeiting the chance to assimilate through marriage. ${ }^{47}$ All these disruptive sentiments are meant to render him more recognizable as a human being, but, of course, they play no decisive role, since from the beginning he is fated to become king of Egypt and Syria. Even if he is a 'foreign' element, he has a predestined role to play in Muslim history.

Because a clear ethnic or linguistic framework for identification is lacking, the religious factor becomes the more significant. Especially during his disciplining of Uthman, Baybars's knowledge and adherence to the articles of the faith are displayed, which he already internalized as a young boy. The story also emphasizes the importance of the law, as a source of social and political order at various levels, protecting the common people, deciding conflicts, neutralizing intrigues, and structuring undertakings and transitions, such as the transfer of royal authority and dealings with the Franks. Nevertheless, in spite of this stress on orthodoxy, it is no coincidence that Baybars's grandfather was a dervish. Even in his youth, his person is linked to the esoteric dimension of life through his descent and the prophecy of his bright future. This link is confirmed by his meetings with such illustrious figures as al-Khadir and Sayyid Ahmad al-Badawi, both important protectors of the faithful, who establish the relationship of the hero with the dimension of spirituality and esotericism and, thereby, with the popular domain of religiosity. The endorsement of al-Khadir turns Baybars into a 'real' Muslim; the support of al-Badawi gives him strong Egyptian credentials.

These religious aspects find expression in various peculiarities of Baybars's character and conduct. His piety is manifested not only in his loyalty to the faith, but also in his attitude in life, which is governed by a strong sense of justice. Even in his early youth, as a forsaken slave boy, Baybars is concerned with the conditions of the common people, protecting them against injustice and oppression. He intuitively acts as the protector of the weak and the poor, and as the natural enemy of hypocritical officials such as qadis and gover- 
nors, who outwardly exhibit piety and obedience to the faith's doctrines, but are actually striving only for their own personal profit and power. Baybars's religiosity is shown, too, by his faithfulness to the cause of the community of Muslims and his fierce stance against its enemies, defined in religious terms, the Christian Franks and the Persian Fire-worshippers. Whereas the Persians are defeated in military campaigns, in which Baybars shows-perhaps somewhat reluctantly — his loyalty to the faith rather than to his ethnic background, the Franks are more persistent, entangling him in a continual sequence of intrigues, campaigns, and schemes. Baybars confronts these challenges indefatigably, always prepared to sacrifice himself for the sake of the Muslims, both in moral and in military issues.

These aspects of Baybars's personality are, of course, intended to compensate for his foreign descent and to provide him with traits that would facilitate his being accepted by the populace. This strategy is especially effective because of the remarkable realism of the sira as a whole. When compared to other romances, in the 'Romance of Baybars' miracles, magic, jinns, and demons are conspicuously scarce. The supernatural phenomena that are inserted are related to the faith and especially to popular religion and the veneration of saints, and are meant to strengthen his position as a popular leader: Through his contacts with Ahmad al-Badawi and al-Khadir, and the saints prophesying his ascendance, he establishes relations with the supernatural realm, which will secure him the protection of the saints. Thus, the diverse elements of hybridity, between history and fiction, between literary and vernacular narrative, between orthodox and popular religiosity, between foreign and indigenous belonging, are not meant to create a sense of wonder and exceptionality, but rather, through realism, to forge a sense of belonging and integrity, a virtuousness which justifies his acceptance by the common people.

This tendency to depict Baybars as a 'round' and credible character is inspired too by the consideration that - unlike the other examples discussed in this chapter-he combines the roles of the hero and the king. At first he is the hero who is the predestined new king, but who still has to pass through a trajectory in which he has to acquire the virtues of the ideal king that will enable him to identify with his subjects. During this time he has to prove his loyalty to the legitimate king. But since this king has no indigenous roots, the only source of legitimacy is family relationships within the Ayyubid dynasty. In spite of his moral and political stature, Baybars is reluctant to assume power, until the dynastic source of legitimacy has expired. Of course, this reluctance is ambivalent, since Baybars knows that his kingship is predestined and that al-Salih Ayyub has appointed him as his successor. Nevertheless, it provides him with an image of integrity and allows him to construct a new source 
of legitimacy: the support of the Mamluk amirs and the Ismaili fidawis. The covenant with which he accepts the throne shows how his personal charisma and morality are combined with political acumen and an understanding of the ways to transform power into a solid base of authority.

\section{The Muslims against the Byzantines: Sayyid Battal}

The last text that we will briefly discuss in this chapter is an Ottoman-Turkish romance in the style and tradition of the Islamic epics, especially the Hamzanama. The hero of the story, Sayyid Battal, is a trickster-hero in the Arabic sira of Dhat al-Himma which probably dates from the twelfth century and which relates the struggle between the early Muslims and the Byzantines. Here, Sayyid Battal is the main hero and it seems that the Ottoman version of his exploits can be connected with the campaigns of the Ottomans against the Byzantine Emperor in the period before the conquest of Constantinople in 1453. In this respect it shows similarity with the epic 'Umar al-Nu'man and his sons', which is extant both as a part of the Thousand and one nights and as a separate text. This story, too, is focused on the struggle between a Muslim king, Umar al-Nu'man, and his sons, to subdue the Byzantine Emperor and conquer the glorious city of Constantinople. In the end the occupation of the city is accomplished not through violence, but through family connections, since at a certain point the Byzantine Emperor turns out to be the (illegitimate) son of Umar and a Greek princess. This epic exists only in Arabic, apparently, although Garcin describes it as an originally Turkish narrative. ${ }^{48}$

In Sayyid Battal several episodes of the exploits of the hero are related, which without exception end with the death of the Byzantine Emperor and begin with the accession of a new one. On the side of the Muslims, the successive caliphs al-Mahdi, al-Mu'tasim, and al-Ma'mun play a marginal role as exponents of the framework of religio-political authority. The story is centred in Malatya, in Anatolia, and spreads out to Tarsus, Caesarea, Baghdad, North Africa, and India. As far as its form and narrative procedures are concerned it follows most of the previous romances, although it is less sophisticated: an emblematic hero-adventurer; a rather repetitious series of incidents and battles; a strong religious component; and a historical setting with supernatural elements. The story also includes a period of absence and a visit to the realm of the jinns, sim-

48 For a summary of this story and references, see Marzolph and Van Leeuwen, The Arabian Nights Encyclopedia; Garcin, Pour une lecture historique. 
ilar to our other examples. References to the 'seven seas', Solomon, and other motifs reveal its affinity with the Hamzanama and the Muslim imagination, and, as we will show below, with the tradition of the Alexander romance. References to the Persian narrative tradition include the figures of Jamasp and Shumas.

In the beginning of the story we find the familiar motifs of interruption and prophecy. This time, however, the prophecy comes not from some anonymous soothsayer or sage, but from the archangel Gabriel himself. While waiting for a new revelation, the Prophet Muhammad is told about the city of Constantinople and its innumerable beauties. Gabriel tells him that after a few hundred years a young man will stand up in Malatya, by the name of Ja'far, who will resemble Hamza and Ali. It is he who will conquer the city for the Muslims and convert the population to Islam. Soon a descendant of Ali, the nephew of the prophet, migrates to Baghdad and subsequently to Malatya. He has a son, Rabi, who begets two sons, Hasan, who is extremely clever, and Husayn, who is a fearsome bahlawan, or warrior.

One day, on one of his expeditions, Husayn enters a cave where he finds a strange horse, and all kinds of weapons and coats-of-mail that belonged to David, Isaac, and Hamza. A mysterious voice explains that all this is meant for a certain Ja'far. In a dream Husayn hears that Ja'far will be his son who will become a magnificent warrior and who will convert the Byzantines to Islam. This dream is confirmed by the birth of Ja'far and by the astrologists who foretell a bright future for the young lad. However, while on a hunting party, Husayn is killed by the Byzantines. When Ja'far is fifteen years old - a strong adolescent, well versed in the four religious books, Quranic interpretation, and the traditions of the prophets, and with a sound sense of judgementhe decides to avenge his father. He girds on the weapons kept in store for him, collects some brave friends, and sets out to fight the Christians, and, later, a Jewish tyrant in North Africa. He is rather brutal in his methods; captives are summoned to adopt the true faith, and if they refuse they are hit on the head so violently that 'the brains squirted out in all directions' 49

The mission of Ja'far is confirmed by the very pious sheykh Abd al-Wahhab, who is 300 years old and has performed the hajj seventy times. He hands him a letter from the prophet, written by Caliph Osman/Uthman, in which Ja'far's destiny is confirmed. He also spits into his mouth some spittle from the prophet personally — the size of a hazelnut — and suddenly Ja'far knows seventy-two 


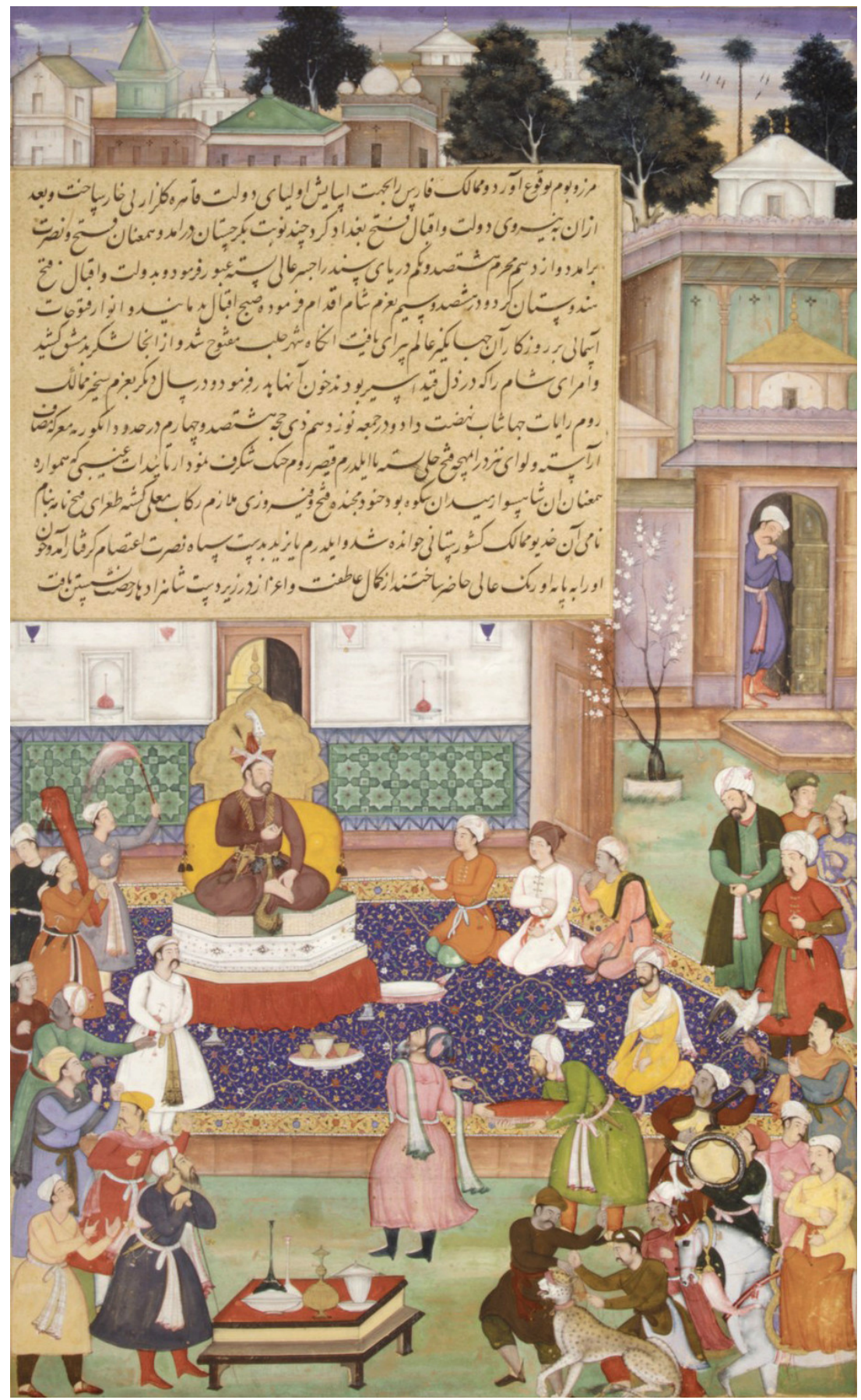

FIGURE 7 The Ottoman Sultan Bayezid before Timur. Akbarnama, ca. 1600. 
languages and twelve sciences. He preserves the letter in an amulet. He also meets the Prophet Khadir several times and the Prophet Elias, who gives him a prayer mat and helps him to revive a dead boy and girl. These miracles show Ja'far's connection with the supernatural forces controlling destiny, which often reveal their signs in dreams. At one point, in the land of Qaf, he meets an effigy of King Alexander, along with one of Aristotle, provided with a table with wise formulae written on it. In the end Ja'far dies as a result of a stone thrown on his chest by the wind, as Fate has decided/ordained.

The adventures of Jafar/Sayyid Battal are mainly built around the opposition between the Christians and the Muslims (apart from the Jewish sorcerer). The contrast between the good and the bad is quite unambiguous: the Christians are consequently depicted in a negative way and are systematically humiliated. At some points Ja'far disguises himself as a Christian monk, mesmerizing his opponents with his brilliant knowledge of the Bible and its exegesis, even making them believe that he is the Messiah. The Christians, in their turn, swear by al-Lat and Manat—rather incredibly—and threaten to kill the caliph and destroy the Kaaba. They are often drunk and finally have to concede a part of Constantinople to Ja'far, who has a mosque constructed for the Friday prayer. During his campaigns, Ja'far marries several times, remarking dryly when criticized for this, that the prophet had nine wives; so why should he, Ja'far, not have two? In the end he has five or six wives, however.

An intriguing episode is Ja'far's adventure with a serpent queen, which seems to echo the story of 'Hasib Karim al-Din' discussed above (Chapter Three). The episode is introduced by presenting a hero eating from a broth from which a snake has eaten. He swells up and explodes as a result. Subsequently, a vizier named Yamlikha tells about a 'Spring of Hell' on a mountain, into which Ja'far is thrown. At the bottom of the well he is approached by serpents, one of which - a big one - carries a small serpent with an emerald head. She introduces herself as Yamlikha, the Queen of the Serpents, and tells him that after Solomon's death she was captured by Buluqiya and Affan. They held her captive for forty days and took her through the mountains, forcing her to explain the functions of all the wondrous phenomena that they encountered on the way. When she was set free she remained in this well, except for one excursion to see Muhammad. The exit from the well is on Mount Qaf.Ja'far stills his hunger by sucking a magical stone; he falls asleep and succeeds in escaping from the well by clinging to a dragon that flies to the surface of the earth. Ja'far immediately performs prayer and recites Qur'anic verses.

This episode is clearly a garbled, and therefore late, version of the story of 'Hasib Karim al-Din', using the motifs without their original coherence. It does not seem to add anything to the story as a whole, except a colourful motif 
and a topical visit of the hero to the underworld. Since the episode is told by Sayyid Battal himself, it even breaks the usual pattern of the narrative, which is told from a third-person perspective. It also refers to the story of Buluqiya, indicating that it was well known at the time, possibly in a Turkish version. These observations, of course, raise intriguing questions with regard to the process of transmission. It is possible that the episode was incorporated into the romance from an Ottoman translation of the 'Jamasp' version, but it may also have been derived from a Persian or Turkish source of another date. Since we know that the story was circulating in the Ottoman Empire, in Turkish and Arabic versions, in the fifteenth and sixteenth centuries, it seems likely that it was incorporated into the 'Romance of Sayyid Battal' in this period, and that the version of the romance that we possess and that has served as the basis for the German translation used here was not compiled at a later date.

As far as visions of kingship are concerned, the narrative is somewhat ambiguous. It portrays 'evil' kings, in the person of the Byzantine emperors and the Jewish sorcerer-king, and legitimate caliphs. The caliphs, however, have a formal role only, because a separate transmission of legitimacy goes directly from Ali and Muhammad to Sayyid Battal, who, therefore, accumulates a high potential of charismatic authority. He is not a king, however, and not even the governor of Malatya, and he acknowledges the sovereignty of the caliph. This ambiguity seems to reflect the situation of the Ottomans at a certain stage in their ascendancy to prominence. The narrative more or less secures their credentials as fighters for the true faith, projecting their power into religious history, and justifying their further expansion to Constantinople-the site of a legitimate, though infidel, dynasty of emperors. The story brings together all the elements necessary to buttress a claim to kingship within the Muslim realm, without being rooted in the Arabic ethnic or linguistic domain. It is the combination of martial strength, religious charisma, and inclusion into the discourse of popular literature and religion that defined the Ottoman claims to what became a powerful sultanate.

\section{Concluding Remarks}

In his study of the fictionalized biographies of Timur Lang that appeared in the eighteenth century in Turkish and Persian, Ron Sela attempts to link the expansion of popular literature to specific historical circumstances. Why did these Timurnamas become popular particularly in the eighteenth century? Are they a reflection of efforts to confront a societal and political crisis that required 
new self-definitions and new visions of the past and the future? Sela's investigations show the importance of situating narratives of this kind-generally indicated as romances of chivalry - within a specific historical setting. They show, too, on the other hand, that by responding to specific situations, they refer to and mobilize concepts, ideas, and discourses that transcend specific historical periods and that are gleaned from traditions with a much broader historical, cultural, and literary scope. It may even be their function to break out of confined cultural/political spaces and link societies in crisis to their wider environment, thereby connecting traditional elements with new impulses and vitality to construct a vision of the future. It seems that this kind of literature is precisely conceived for this aim: to preserve ahistorical, trans-historical, or essential concepts and discourses within a narrative 'container' to confront and assimilate new tendencies in order to realize a new equilibrium. These narratives should provide continuity, but allow for transformation over the course of time. ${ }^{50}$

In several instances, Sela compares the Timurnama with the 'Romance of Baybars' that we analysed above. Both texts are fictionalized biographies; both texts are about the rise to power of a forsaken infant, following an earlier prophecy; both texts are legitimations of rulership not rooted in tradition that they attempt to embed in a broader context; both texts contain elements of mysticism and popular religion; both texts, finally, are about heroes hailing from Central Asia. Of course, these similarities may be coincidental, as they are to some extent influenced by generic conventions and thus imposed by the nexus between form and content, They may also be the result of direct influence, however, rendering the 'Romance of Baybars' into a kind of transformed Timurnama, containing the same values and tastes. It is also possible that the 'Romance of Baybars' and the Timurnama have similar characteristics because they belong to a period in which similar visions, needs, and tastes emerged. In this third hypothesis, the resemblance in generic conventions and the popularity of the genre are not coincidental or the result of direct influence, but rather the effect of a broader space of transmission and the formation of new common interests and concerns. Perhaps in Egypt a sense of crisis occurred similar to that of Central Asia, while simultaneously Central Asia-represented by the figures of Timur and Baybars - was experienced as part of a familiar discursive tradition. It is perhaps not inevitable, but also not a coincidence, that so much of the material discussed in this chapter is datable to the period 1500-1800, and

$5^{\circ}$ Ron Sela, The Legendary Biographies of Tamerlane. Islam and Heroic Apocrypha in Central Asia (Cambridge etc., 2011). 
in particular to the seventeenth and eighteenth centuries, when a new phase of Eurasian interactions set in.

In their multifaceted hybridity, the romances fit nicely into the category of semi-popular literature, combining elements from popular lore with courtly discourses of authority. As Sela aptly phrases it for the Timurnama:

The two historical realms, the courtly and the popular, were connected by the circumstances of their formation and the issues that they addressed-from the changing perceptions of the ruler's identity and the legitimacy of its rule, $[\ldots]$ to the relationship between religion and state; from their interpretations of traditions and invocation of sources of inspiration to their understanding of their place in the world. ${ }^{51}$

As such, the narratives are clearly bound by generic imperatives, defining form, structure, and motifs to a large extent, showing remarkable parallels. Besides these procedural aspects, we encounter some motifs that transcend the generic type and can be linked to narratives of other types, discussed in the previous chapters, such as the motif of interruption, prophecy, and destiny, and, significantly, the composite nature of power and authority. When authority is concentrated in the figure of the king, it is highly symbolic, even abstract; in order to be efficient, it needs to be linked to the ad hoc insights of viziers and the ad hoc power of the hero-warriors. This connection can lead to harmony only if all participants are unified in a moral idea, a common vision of the moral constituents of the community and rulership.

This ideological component is directly connected to the formal characteristics of the narratives, such as the enactment of the intrigues, the distribution and nature of the various roles, the binarity of the narrative dynamics, the emblematic nature of protagonists and events, the embedding in popular culture, etc. This seems to be the common ground in which dialectic views shape common discourses, where the daily practices of power can be transformed into the symbolic meanings in which values can be explained, exemplified, and preserved, as a framework to confront historical disruptions. Although the geographical and cultural parameters are often vague, the romances do evoke a sense of communality, often related to centres of power and symbolic capital. Constantinople is an exemplary case of a city that has hoarded so many historical connotations that it can easily survive - and perhaps even requires - the transition from Greek to Turkish domination.

$51 \quad$ Ibid., 141. 
As we have seen, cultural, linguistic, ethnic, and political markers all have a role in the interplay between centripetal and centrifugal forces, determining the distribution of good and evil, enemies and allies. But a community is primarily defined by its moral values and its ability to project these onto their king. To achieve this, the hero acts both as a container, collecting the required symbols of morality, and as a medium, imbuing these values in society, and, especially, in the figure of the king, in order to restore the equilibrium between moral contents and historical forces and to preserve or revitalize the exemplary role of the king. We have seen that in several of the romances the influence of women is of vital importance, mostly in a positive sense. In the next chapter we will highlight some aspects of the female role in the issues that are so central in discourses of kingship and that usually derive their narrative potential from a forceful phenomenon: love. 